Portland State University

PDXScholar

1974

\title{
Validation of the Oregon school entrance speech screening test
}

Patricia Ann Hamilton

Portland State University

Follow this and additional works at: https://pdxscholar.library.pdx.edu/open_access_etds

Part of the Speech and Hearing Science Commons

Let us know how access to this document benefits you.

\section{Recommended Citation}

Hamilton, Patricia Ann, "Validation of the Oregon school entrance speech screening test" (1974). Dissertations and Theses. Paper 1989.

https://doi.org/10.15760/etd.1988

This Thesis is brought to you for free and open access. It has been accepted for inclusion in Dissertations and Theses by an authorized administrator of PDXScholar. Please contact us if we can make this document more accessible: pdxscholar@pdx.edu. 
AN ABSTBACT OF THE THESIS of Patricia Ann Damilton for the Master of Science in Speech: Emphasis in Speech Pathology and Audiology presented June 5, 1974 .

Title: Validation of the Oregon School Ertrance Speecb Screening Test. APPROVED BY MEMBERS OF THE THESTS COMMITTEE:

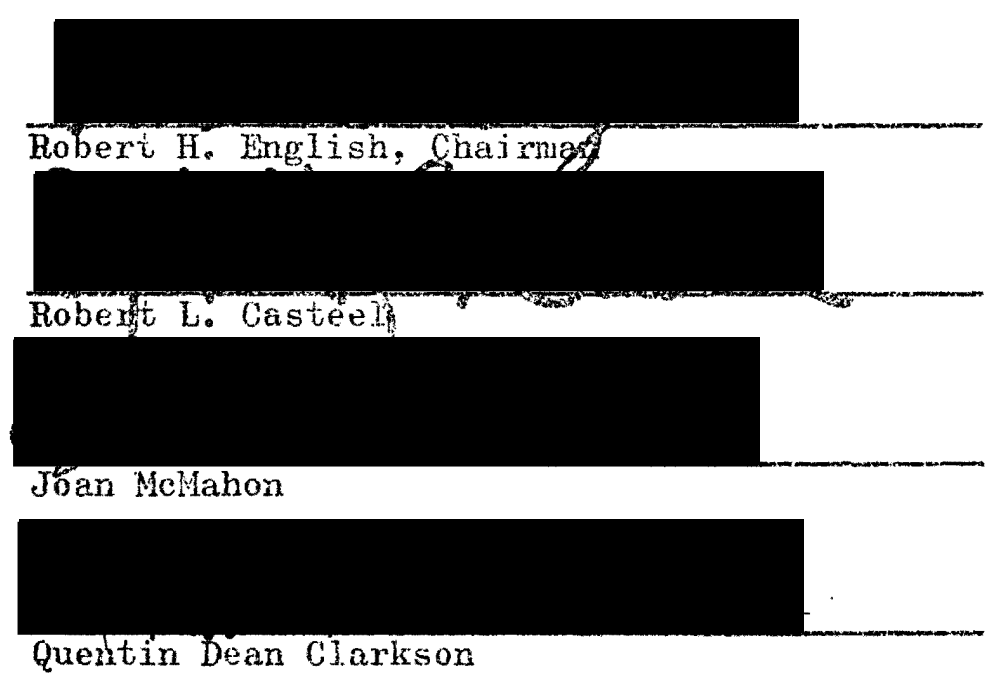

This study was designed to validate a speech screening device entitled the Orecon School Entrance Speech Scraening Test. the 0sESST was developed to identify quickly those childeen entering first grade who are in need of speech and language intervention. The present study sought to determine what proportion of children with spech and language disorders was not detected by the screening test and what proportion ot chijdren without speech and language disorciers iailed the 0SESST. To addition, this gtudy undertook to deternine whether results of this investigation are consistent with those obtained on the OSnSST in areas 
of articulation, syntax, language reception and expression, voice, and speech fluency.

Subjects for this investigation were forty children just entering first grade in Tillamook County. Twenty-one were randomly selected from those who passed the screening test and nineteen from those who failed. This investigator received the forty subjects in random order and without prior knowledge of which children passed or failed the screening test.

Three standardized tests were used to evaluate the speech and language of the subjects: the Photo Articulation Test (Pendergast et al al., 1965), the Utah Test of Language Development (Mecham et al., 1969), and the Northwestern Syntax Screening Test (Lee, 1970). The Jewish Hospital Voice Profile (Wilson, 1970) was completed for each subject to assess the parameters of voice. Bloodstein's Developmental Phases of Stuttering (Luper and Mulder, 1964) and the Stuttering Severity Instrument (Riley, 1972) were utilized to assess rhythm disorders.

Results of tests used in the validity study were compared with results of the screening test. Analysis showed the 0SESST produced six false negatives, or 15 percent of those tested passed the screening test but failed the validity tests. Four false positives or 10 percent of the subjects failed the OSESST and passed the validity tests.

Analysis of individual tests revealed that all the OSESST subtests except voice and fluency produced false positives and false negatives. Voice subtests, as well as fluency subtests, produced 100 percent agreement. The largest amount of false negatives was produced in the articulation test. These errors, however, were all mild in severity and would not be treated by most speech clinicians. The two language and syntax 
false negatives were of more concern. These subjects, which were delayed in language skills by more than one year, should have been detected by the screening test. Fortunately, only one subject passed the entire screening test with moderate to severe problems. Additional subjects, although undetected by certain parts of the OSESST, were failed in another area. Thus, the four who should have failed syntax but did not, failed language or articulation and were identified for further diagnostic testing and possible intervention.

The voice and fluency subtests were found to be valid measures. The investigator, however, recommended modifications for the articulation and language portions, and suggested that the syntax subtest be replaced as it did not identify those children with syntactical problems. 
VALIDATION OF THE OREGON SCHOOI ENTRANCE

SPEECH SCREENING TEST

\author{
by \\ PATRICIA ANN HAMILTON
}

A thesis submitted in partial fulfillment of the requirements for the degree of

MASTER OF SCIENCE IN SPEECH:

EMPHASIS SPEECH PATHOLOGY AND AUDTOLOGY

$$
\text { Portland State University }
$$

1974 
TO THE OFFICE OF GRADUATE STUDIES AND RESEARCH:

The members of the Committee approve the thesis of Patricia Ann Hamilton presented June 5, 1974.
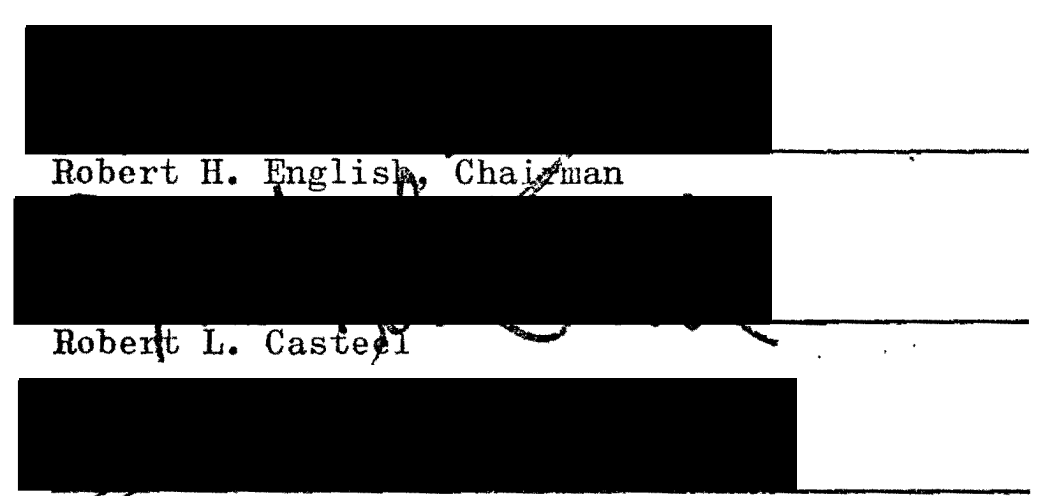

JGan McMahon

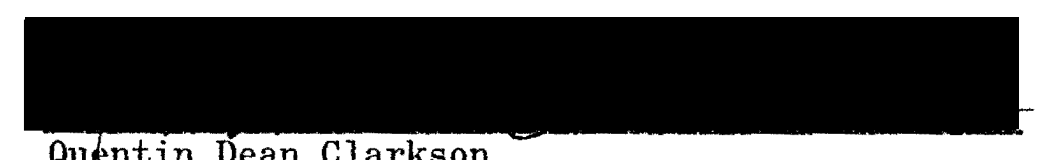

Quentin Dean Clarkson

APPROVED:

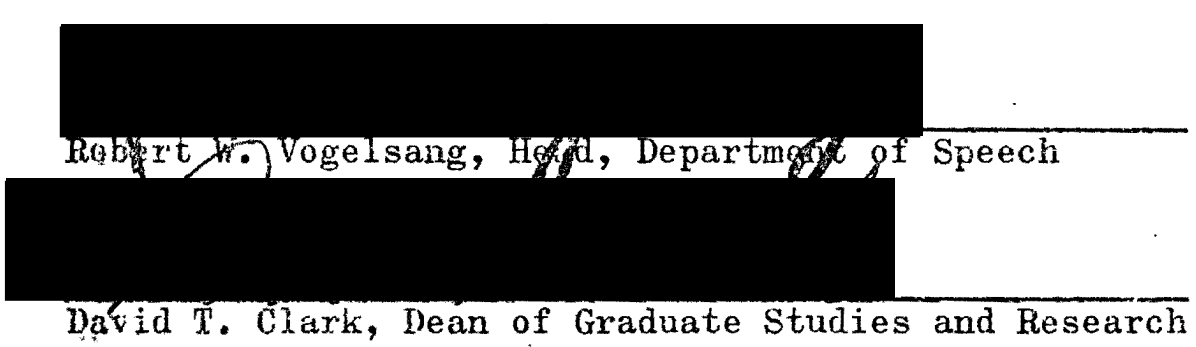




\section{ACKNOWLEDGMENTS}

My sincere gratitude is extended to the members of my committee, Dr. Robert H. English, Dr. Robert L. Casteel, Joan McMahon, and Dr. Quentin D. Clarkson, for their valuable ideas, suggestions, and support. I am deeply grateful to Dr. English, my chairman, for his patience and ready guidance of me throughout the writing of this thesis. I thank Dr. John H. Gilberts of the University of Oregon. Medical School for suggesting this study, and Jim Casciato and Brian Hines for their help and technical assistance.

To the Tillamook County Health Department staff and to the children and their parents with whom I worked, I extend my appreciation for the cooperation they gave me, which made the testing of my forty "subjects" an enjoyable experience.

My appreciation and thanks to Leslie Grueger, who typed this final copy of my study and offered many helpful suggestions. Finally, I give my love and thanks to my husband, Dick, and my children, Lezlie, Julie, and Tracey, for their patience, help, and encouragement, and for allowing me to "do my thing!" 
TABLE OF CONTENTS

PAGE

ACKNOWLEDGMENTS

iij

LIST

F TABLES.

vii

\section{CHAPTER}

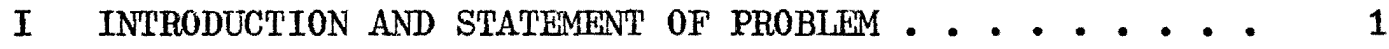

I Introduction . . . . . . . . . . . . 1

II Statement of the Problem. . . . . . . . 4

III Specific Questions to Be Answered. ....... 4

II REVIEW OF THE LTTERATURE. . . . . . . . . . 5

I Screening in General ............ 5

II Articulation Screening Methods and Devices. . . 10 Screening Methods............ 10

Screening Devices . . . . . . . . 13

III Language Screening Devices . . . . . . . 16

IV Combined Screening Devices. . . . . . . 18

III PROCLDURES. . . . . . . . . . . . . . 21

I Subjects . . . . . . . . . . . 21

II Instrumentation . . . . . . . . . 22

Utah Test of Language Development ... . . . 23

Northwestern Syntax Screening Test. . . . . 24

Photo Articulation Test . . . . . . . . . 25 
CHAPTER

PAGE

Jewish Hospital Voice Profile . . . . . . • . 26

Bloodstein's Developmental Phases of Stuttering . 26

III Investigator Reliability . . . . . . . . . . 27

IV Testing Environment . . . . . . . . . . . 27

V Data Analysis. . . . . . . . . . . . . . . 29

IV RESULTS AND DISCUSSION OF RESULTS . • • • • • • • • . 30

I Results. . . . . . . . . . . . . . . 30

Overall Results . . . . . . . . . . . . 30

Individual Test Results . . . . . . . . . 32

Consolidated Test Results . . . . . . . . 36

II Discussion of Results . . . . . . . . . . . 39

Overall Results................. 39

Individual Test Results . . . . . . . . . . 41

V SUMMARY AND IMPLICATIONS. . . . . . . . . . . . . 48

I Summary. . . . . . . . . . . . . . . 48

II Implications. . . . . . . . . . . . . . 50

Future Application. . . . . . . . . . . 50

Future Research . . . . . . . . . . . . 51

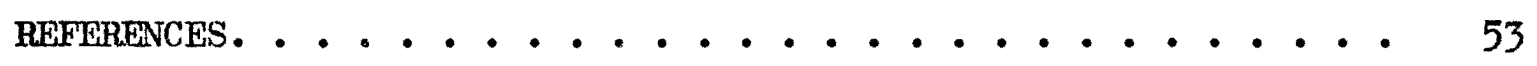

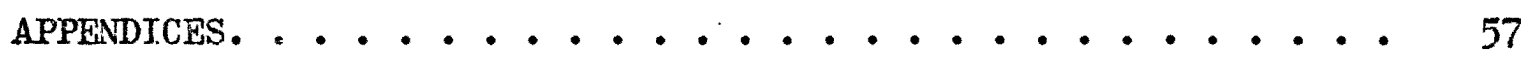

A Oregon School Fontrance Speech Screening Test. . . . . . 57

B Utah Test of Language Development . . . . . . . . . . 60

c Northwestern Syntax Screening Test. . . . . . . . . 63 
PAGE

D Photo Articulation Test . . . . . . . . . 65

E Jewish Hospital Voice Profile . . . . . . . . 70

F Bloodstein's Developmental Phases of Stuttering . . . 71

G Stuttering Severity Instrument. . . . . . . . 75

H OSESST and Validity Tests Raw Data. . . . . . 76 


\section{LIST OF TABLES}

\section{TABLE}

\section{PAGE}

I 0verall Test Results . . . . . . . . . . 31

II Articulation Test Results . . . . . . . 32

III Language Test Results . . . . . . . . . 33

IV Syntax Test Results. . . . . . . . . . 34

V Voice Evaluation Results . . . . . . . . . 35

VI Fluency Evaluation Results . . . . . . . 36

VII Consolidated Results of the OSESST and

the Validity Study . . . . . . . . . . 


\section{CHAPTER I}

\section{INTRODUCTION AND STATEMENT OF PROBLEM}

\section{INTRODUCTION}

I'se importance of early identification of children with speech and language problems has been recognized by education and medicine in recent years, and has been given equal consideration with detection of disease and visual and hearing difficulties. To identify children in need of language and speech services is a primary responsibility of most public school speech clinicians. They commonly utilize various screening methods to select children within a school population who may require further diagnostic evaluation and/or treatment. Screening is an evaluational method utilized to survey a large population of children in order to locate those with speech and language disorders. Ideally, the screening procedure requires only a few minutes to administer and elicits a good sample of consonant and vowel sounds in counected speech, as well as syntactical and semantic ability (Sanders, 1972; Fluharty, 1974).

In districts with established speech programs and in those which have never had speech services, careful planning is essential to insure an efficient and orderly screening procedure. Many times screening methods are based on tradition, personal preference, directives from the school district, et cetera, and frequently lack standardized procedures (Black, 1964; Johnson et al., 1967; Sanders, 1972). Those 
instruments available in standardized form are often too lengthy to be administered to large groups of children (Perkins, 1971); hence, they do not meet one of the prime criteria for a screening device: that it require only a few minutes to administer.

The Oregon School Entrance Speech Screening Test (OSESST) was designed to be administered quickly in four to seven minutes to firstgrade children. It was developed as part of the three-hour MultiModular Health Examination (Anderson, 1972) during which children entering school are evaluated by a series of health specialists in one location. Each child is evaluated in terms of nutrition, medical history, emotional health, speech, hearing, vision, school readiness, physical health, and immunization status.

The speech screening test (refer to Appendix A) includes four subtests to assess the parameters of language, articulation, rojce, and fluency. The only materials needed are two chairs, a table, and eight color cards (red, blue, green, yellow, white, brown, black, and orange).

The articulation test is made up of words from the BuckinghamDolch Combined Word Lists (1936) which show the most commonly used words for American-English-speaking persons. Those words include each sound in the initial, medial, and final positions, and are arranged in ordex of development in the speech of young children according to the nomes established by Templin (1957). Any exror at or below a child's age level constitutes a failure of the articulation subtest.

Syntax is evaluated by eliciting a language sample from the child by asking him open-ended questions about himself. The examiner encourages the child to talk until he says five sentences. From this sample 
the clinician determines whether the child uses plurals, articles, pronouns, and conjunctions. A mean length of response is determined by dividing the total number of words in five sentences by five. If the child does not use four to six word sentences or all the parts of speech mentioned above, he fails this subtest.

Language expression is screened by using selected items from the Stanford Binet Intelligence Scale (Terman and Merrill, 1960) and the Wechsler Intelligence Scale for Children (1949) which cover body parts, color concepts, and general knowledge. The child must name six of eight body parts in the first section, six of eight colors in the second, and answer all five questions correctly in the general knowledge section. Failure to meet any of these criteria is a failure for this subtest.

The parameters of voice and speech fluency are judged clinically through the screening to be normal or abnormal, i.e., passing or failing. A failure in either subtest, voice or fluency, constitutes a failure for the whole test and a consequent referral for further diagnostic testing and intervention.

After the OSESST was used to screen more than 300 children, it appeared the test successfully identified children with speech and language deviations. The validity of the screening test, however, remained to be determined. More specifically, the need arose to verify whether or not this short screening device effectively discriminates those children who are in need of speech and language intervention. Hence, the present investigation was designed as a validation study of the OSESST. 
II STATEMENT OF THE PROBLEM

The purpose of the present study was to determine if the Oregon School Entrance Speech Screening Test can effectively identify those children entering first grade in Tillamook County who are in need of more thorough diagnostic testing and possible treatment. In addition, this study sought to determine whether the results of this investigation are consistent with those obtained on the OSESST in the following speech and language areas: articulation, syntax, language, voice, and speech fluency.

\section{SPECIFIC QUESTIONS TO BE ANSWERED}

As a validation study, the present investigation has confined itself to answering the following two specific questions:

1. What are the estimated false negatives, i.e., what proportion of children with speech and language disorders was not detected or was passed by the 0SESST?

2. What are the estimated false positives, i.e., what proportion of children without speech and language disorders failed the OSESST? 
CHAPTER II

REVIEW OF THE LTTERATURE

Screening or surveying may be defined as an evaluational procedure utilized to survey a large population of children in order to locate those with speech and language disorders who may need further diagnostic testing and speech intervention. Although some speech clinicians rely upon teacher referrals of problem children, many clinicians throughout the country conduct annual or biannual speech screening surveys at the elementary school level to identify which students are in need of speech intervention.

Literature dealing with screening or survey methods will be dism cussed under four headings: Screening in General; Articulation Screening Methods and Devices; Language Screening Devices; and Combined Screening Devices.

\section{SCREENING IN GENERAL}

Ainsworth (1948) notes the first job of a school speech clinician i. to find the children who need help and that the most satisfactory way is to conduct a survey. With the survey method each child is interviewed and those who need further testing noted for later diagnostic tests. During the interview the clinician may ask the child's name, age, grade, et cetera. Ainsworth feels it is well to have a routine to 
follow in obtaining a sample of the child's speech. This kind of screening takes about two minutes per child.

Irwin (1953) refers to the "Personal Interview Method" by which the clinician interviews each child. She feels this method should not involve too many children. In Illinois, according to Irwin, the total number may not exceed 1,000 children per clinician as such a population will yield enough children to fill the case load. The screening process should take about two minutes per child, and questions relative to the child's articulation ability and general speech intelligibility should be answered.

Screening procedures within schools differ in their administration and organization. Eisenson and 0gilvie $(1957,1963)$ mention the following methods: 1) in some instances teachers refer the speechhandicapped child to the correctionist; 2) in others the principal, parent, school nurse, psychologist, or guidance director refers the child to the correctionist; and 3) the correctionist makes a survey. Eisenson and Ogilvie (1971) indicated most clinicians preferred the survey method.

Van Riper (1963) emphasizes the need for screening in schools where each year large numbers of children enter the elementary grades. The clinician must first identify those children with speech disorders; analysis will come later. Some of the common methods used in the initial screening are enumerated by Van Riper: 1) the naming of objects or pictures selected so as to include all the major speech sounds; 2) the repetition of test sentences such as "This girl thinks that cowboys on the TV are real" or a series of sentences, each designed to 
test the errors on just one sound; 3) serial speech responses such as counting, naming the days of the week, and naming colors on a chart; 4) repeating nonsense syllables or sounds in isolation or nonsense words; and 5) conversation and questioning.

Screening or surveying, as defined by Black (1964), is the process of selecting children with whom the speech clinician will work. Black also uses the word "screening" to mean the process of selecting from this group of children with speech disorders those who need immediate therapy. This method, therefore, requires two screenings, an initial and a secondary screening. The term "identification," as defined by Black, closely resembles the definition of "screening" used in this study. It is, according to Black, a ". . process of hearing the speech of all the pupils for the purpose of selecting those who, after a more careful diagnosis, may be given therapy." Speech clinicians do this initial screening in different ways and with different materials but their major purpose is to evoke an adequate speech sample and to evaluate its deviancy. Black recommends asking a few questions such as: "How did you come to school today? With whom? What pets do you have? What is your dog's name? Color?" In a rapid screening it is well to begin with the sounds most frequently defective, such as: $/ \mathrm{s} /, / \mathrm{r} /, \mid \mathrm{Q} /$, et cetera. She suggests using objects, puppets, and interesting action pictures to encourage speech. The clinician must be alert to recognize voice problems, concentrating completely on voice for a sentence or two. Stuttexing is sometimes difficult to evoke in a survey and the clinician may want to put pressure on a student by hur- 
rying him when his speech appears to be hesitant, controlled with a conscious effort, or has odd pauses.

Tohnson et al. (1967) state that the survey method is probably the most thorough procedure for locating children with speech problems. This method is designed to screen out quickly those children wha have difficulties by means of a short test, administered individually. They suggest the clinician ask the child to name pictures containing the ten most difficult consonants as they occur in all positions in words.

West and Ansberry (1968) state that the method of identification which probably serves both the clinician and the patient best is normally a screening program conducted by trained personnel. Such screening separates the individuals with identifiable speech and hearing problems from those of the group with normal levels in these areas. This procedure is best suited to a school system or other organization in which a relatively large number of individuals can or should be tested. Screening programs are usually developed to locate the pupils who have articulatory problems but the examiner also will have an opportunity to find those who stutter; those with voice problems, and to some extent isolate those with language problems. They believe children with these problems of language, symbolization, and disfluency will generally be subject to referral by the classroom teacher or counsellor, although occasionally one may be first located in a survey. If the child is a nonreader, pictures or objects are generally used to stimulate responses that will include the various sounds. This should be accompanied by a short conversation with the child to determine if there are deviations in his normal communication which are not obvious 
in naming pictures or objects. If time is a problem, one may use test material involving only sounds most likely to be defective. It will depend on the age of the child, but the sounds which need to be checked will usually include $/ \mathrm{s} /, / \mathrm{r} /, / 1 /, / \mathrm{k} / \mathrm{g} /, / \theta /, / \mathrm{f} /$, and / $/$. These authors feel that checking the sounds in the initial position in a word ordinarily suffices to obtain the necessary information. They suggest spontaneous naming of objects or pictures rather than the imitation of words in a more thorough screening program.

An examination of the survey or screening method is made by Sommers (1969), who states that a speech survey should assess, as exactly as possible, the prevalence of speech problems. The degree of exactness depends upon the ultimate use of the data gathered, the existence of adequate techniques for conducting the survey, and the efficiency required to make it practical. He notes that clinicians not comfortable utilizing the basic screening tests may find additional ways of obtaining speech samples, particularly spontaneous speech production. Frequently, the clinician may try to elicit a sample of a child's speech by asking certain questions: "How old are you? Where do you live? What do you like to watch on television?" Another technique consists of asking the child to recite learned material, such as counting from one to ten or saying the Pledge of Allegiance. In summary, Sonmers contends that screening tests can be either very simple and brief or more elaborate and time-consuming. None is really intensive or diagnostic, nor are the tests intended to be so, since the need is to identify speech probiems so that further assessments can be made at a later time. 
II ARTICULATION SCREENING METHODS AND DEVICES

Screening Methods

Before the various articulation screening devices comercially available are reviewed, opinions regarding articulation screening in general will be discussed.

Nichols (1966) writes: "It is in the area of diagnostic procedures that the greatest change in the public school speech and hearing programs has been seen over the course of the past decade." Notable among these procedures, he felt, were studies directed toward valid, reliable, and economical identification of children with speech and hearing defects. Articulation screening devices were the most thoroughly studied.

Commonly, an instrument for testing articulation is chosen because it can be administered easily and quickly, with a high degree of accuracy, yet sort out those having speech problems from those who do not (Sommers, 1969). This type of test Sommers calls a screening test as it sets parameters of performance at a fixed level and runs subjects against those predetermined standards. Subjects whose performances fall below the established standards of performance should receive more elaborate and intensive testing later in the form of the so-called diagnostic test.

A frequently-used speech screening device, according to Somers, consists of picture cards constructed so that each card allows the examiner to judge the correctness of a subject's response to naming the picture. Sounds are tested as they occur in the initial, medial, and 
final positions in words. Clinicians can make their own tests with a set of thirty cards, using the ten most difficult consonant sounds:

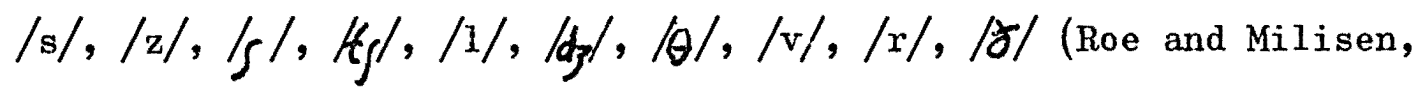
1942; Templin, 1953; and Pendergast, 1963). This type of screening test can be administered in about five minutes, and although it is intended as a screening test for articulation, Sommers believes experienced clinicians usually listen for the voice and rhythmic qualities of speech as well.

Screening for articulation problems is described by Winitz (1969). When an articulatory test is used to compare a child's articulatory performance with that of his peers, it is referred to as a screening test. The child's total articulation score, irrespective of specific errors, is first determined. This score is then compared with a cut-off score which separates adequate from inadequate performance. The cat-off score is a statistical score determined in advance for all the age levels for which the test is designed. Screening tests of this sort have only one function, according to Winitz: to compare a child's articulatory score with that of his peers. In some ways the test is similar to height and weight tests. For these tests a person's score is assessed reiative to all other scores; a score is considered "above or below average" with respect to the distribution of all the scores. Whan the child's score falls at one or the other end of the distribution, it may be considered to be defective in height and weight tests. Winitz gives two reasons for questioning the value of this type of test when used with articulatory responses. First, many children have a single consistent error $\left(e_{.} ., / w /\right.$ for $\left./ x /\right)$ and require intensive 
instruction; therefore, it is unreasonable to select a child for articulatory instruction on the basis of his "total" sound errors. Second, it is unreasonable to select a child for articulatory instruction when he may improve without speech correction. Winitz concludes that a statistical norm may be only one of several criteria that should be used in a screening test. Some others are: level of developmental achievement of phoneme contrasts; level of artjculatory performance needed for beginning school; parental concern; and knowledge as to whether the sound will be corrected by the child.

Perkins (1971) discusses traditional methods of screening articulation and states that screening examinations are utilized when a quick decision must be made about the general adequacy of articulation. Such tests are used extensively in public schools at the beginning of the school year to locate children with defective speech. The major value of screening tests is to separate those who may need help from those who probably do not. Frequently, these tests are constructed by the individual clinician for his own specific need, although they are available in standardized form.

Sanders (1972) also discusses the use of articulation screening tests. They are commonly used by school speech clinicians to select those children from a school population who evidence speech errors and may require intervention. She states that screening tests are used also to rule cut articulation disorders in children referred to the clinician because of other speech or language problems, such as stuttering or voice disorders. A good screening test requires only a few minutes to administer and elicits a sample of consonants and vowels in 
connected speech. Sanders feels the most valid screening test is spontaneous speech, as it is most likely to yield a sample of the habitual articulation in a child. Pictures or objects can be used to encourage spontaneous conversation or the child can be asked to repeat sentences containing frequently misarticulated sounds. The second method yields a inore representative sample of habitual articulation if the clinician tells, and the child repeats, a short absorbing story, sentence by sentence. Other commonly-used methods involve recitation of name, address, age, counting to ten, and naming the days of the week or months of the year.

Screening Devices

According to Irwin (1953), Templin's Non-Diagnostic Articulation Word and Sentence Test (1947) is a reliable tool for discriminating between poor and good articulation in general speech surveys. It includes forty words and eighteen sentences to be read by the subject. This test is limited to those children with reading ability and is not suitable for those entering first grade.

Speech in the Classroom, accompanied by a set of Speech Improvement Cards, is a more formal screening test presented by Bryngelson and Glaspey (1951). It consists of pictures of objects on sixteen cards designed to test sixteen sounds in particular positions in words. Sandera (1972) relates that although the test does not include all consonants and vowels and does not elicit connected speech, it does provide a sample of the more commonly misarticulated sounds. 
Reading material suitable for screening has been developed, such as "My Grandfather" (Van Riper, 1954). These reading materials are usually "graded" in two ways according to Sommers (1969). First, they are developed so that the reading difficulty level is appropriate for use with upper elementary-age children or for junior and senior high school students. Second, they are "graded" in the sense that almost all consonant and vowel sounds are represented as they occur in the injtial, medial, and final positions in words. Most are one-paragraph readings of approximately 120 words or less. The normal reader at the upper elementary and high school level can read such material in two to three minutes.

The Templin-Darley screening test (Templin and Darley, 1961) is the most thoroughly studied speech screening procedure according to Nichols (1966). The reliability of the Templin-Darley test has been found consistently to be in excess of .90 and its validity has been demonstrated in that it is correlated with listener judgements at the .92 level. Nichols also found the cost of the Templin-Darley test, in terms of time expended, averaged two and a half minutes. He feels the best procedure for screening articulation is the Templin-Darley screening test.

Winitz (1969) comments on the fifty-item version of the TempiinDarley Articulation Test. He feels screening tests which assess a person's score relative to all other scores are useful in determining some physical or behavioral traits but are of limited value when used with articulatory responses. Articulation tests of this nature do not consider the criteria mentioned earlier in this paper, i.e., develop- 
mental level of the sound, articulatory performance necessary for the child; concern of the parents; and self-correction.

Sanders (1972) feels that the Templin-Darley screening test is probably too lengthy (actual administration time is not reported) to be useful as a screening test, and not comprehensive enough to be used as a diagnostic test, since it does not contain a sample of all speech sounds.

A recent test, Denver Articulation Screening Exam (DASE), is described by Drumwright et a]. (1973). Screening for a symptomatic disorder has come to the forefront with the development of a system for delivering comprehensive health care to large populations in the most economical manner. The authors feel that screening tests are not intended to be diagnostic. Instead, such tests and procedures are tools for identifying the individual who is likely to have a particular problem. These tests should be well enough designed, they state, to enable nonprofessionals to administer them efficiently and accurately after a short training period. The reliable screening results obtained by noaprofessionals make it possible to concentrate the use of more elaborate and expensive diagnostic procedures and professional time on those individuals most likely to have the disorder under study. The purpose of the DASE is to discriminate reliably between significant developmental delay and normal variations in the acquisition of speech sounds among children from economically disadvantaged backgrounds. The test is designed to detect those children with articulation deviations related to hyponasality, hypernasality, lateral lisp, and tongue thrust. The authors state the test is simple to use and can be scored accu- 
rately and objectively by persons who are not speech clinicians. Validation studies using nonprofessional screeners established the fifteenth percentile as the cut-off point for referral of abnormal children. Test-retest reliability was .95 .

\section{LANGUAGE SCREENING DEVICES}

In 1966 Nichols wrote: "Validated, reliable, and economical screening procedures for the identification of voice, stuttering and language disabilities are not available to the public school specialist." Recently, however, language screening tests have been published. One of the earliest was the Northwestern Syntax Screening Test (Lee, 1970) which identifies those children three to eight years old for whom detailed receptive and expressive evaluations are desirable. It makes a comparison between receptive and expressive use of such granmatical features as prepositions, personal pronouns, negatives, plurals, reflexive pronouns, verb tenses, subject-object identification, possessives, wh-questions, yes-no questions, passives, and indirect objects. Average time required to administer this test is fifteen minutes per child, which may be undesirable for large scale screening projects. To shorten the test, Sanders (1972) suggests the clinician discontinue administering a subtest (receptive or expressive) if the child misses the first ten items. In this case it is probable he also might fail most of the other items. The test also may be discontinued when the child performs successfully on enough items to reach a score comparable to the tenth percentile for his age level. This would indicate he passed at a screening level. Sanders cautions that in order to use the norma- 
tive data the entire receptive or expressive portions must be given.

Mecham et al. (1973) have adapted the Utah Test of Language Development (1967) for screening of language abilities. The use of the abbreviated form of the UTLD is an efficient way to obviate extended testing of a large group of children merely to determine where each falls on the continuum of problem/nonproblem. Mecham et al. feel screening tests used by speech and hearing clinicians in the public schools measure only the articulatory aspects of oral language. Tests which assess the child's mastery of other aspects of language, such as the Illinois Test of Psycholinguistic Abilities (ITPA) by Kirk et al. (1968) or the Bellugi-Klima Language Evaluation Measure (Bellugi-Klima, 1968), are feit to be too time-consuming for practical use in the screening process and are not used routinely for that purpose. The UTLD is a screening instrument constructed to assess both the onset and the progressive maturation of a number of developmental milestones in children's language. It takes approximately a half hour to administer, which may be too much time to allot for screening of children entering school. An analysis of the UTLD was made by Beckstead (1972) to see if. certain combinations could be used efficiently with less time involved for screening purposes. The administration of five particular items seemed to be the most productive short-test for screening purposes since it took only about two and one-half minutes to administer. That particular combination agreed 100 percent in screening out the 163 kindergarten children with a Language-Age-Equivalent (LAE) score of one year or more below their chronological age. Since there is a close correlation between general test results of the UTLD and the ITPA 
(Mecham et al., 1973), the authors feel the short version of the UTLD should be considered for mass screening and the full version for rechecking those screened out by the short form.

\section{COMBINED SCREWNING DEVICES}

Monsees and Berman (1968) described their original speech and language screening test for use with children enrolled in a sumer Headstart program. Items from developmental scales and tests at the four- and five-year-old level were selected. The child is asked to teil his full name and age, compose a story about some pictures, name objects and actions, identify body parts, and follow directions demonstrating knowledge of prepositions. The entire test takes about five minutes to administer and quickly evaluates the articulation, vocabulary, and expressive language abilities of culturally-deprived Negro children. Studies of validity and reliability of the test were not undertaken.

The Denver Developmental Screening Test (Frankenburg and Dodds, 1970) is designed to identify children with serious developmental delays. The language part of the test is constructed to elicit verbal responses from children by means of pictures and objects. It can be used with children one month to six years old and requires twenty to thirty minutes to administer the four sections: gross motor, language; fine motor-adaptive, and personal-social. The test is standardized only when given in its entirety; individual sections may yield insufficient information. 
The Daberon (1972) is a screening tool developed to sample the knowledge and skills of four-, five-, and six-year-old children as they begin school. It assesses several language skills, including knowledge of body parts, color and number concepts, functional use of prepositions, plurals, and the ability to follow directions; and surveys general knowledge, visual perception, gross motor development, and the ability to categorize. This test does not yield a score but the authors feel a high degree of inaccurate responses may indicate future problerin areas. Research on standardization has not been done but probable developmental ages for each item are listed in the manual. Fluharty (1974) has designed and completed a preliminary standardization of a speech and language screening test for preschool children which, as yet, is not published. She found currently available speech and language procedures do not seem to assess all aspects of speech and language in a manner suitable for use with large numbers of children three to five years old. Consequently, speech clinicians frequently screen children by means of subjectively chosen speech and language tasks. Fluharty's test purports to assess the articulation, vocabulary, and receptive and expressive language abilities of preschool children. The thirty-five-item screening test is designed in three parts: Section A uses the identification of fifteen common abjects to evaluate the child's vocabulary level and articulatory proficiency; Section $B$ provides an indication of the child's receptive language abilities by requiring nonverbal responses to sentences incorporating ten basic syntactic structures; and Section $C$ evaluates expressive language by asking the child to imitate ten one-sentence picture descrip- 
tions of photographs. The administration time is from five to seven minutes. Both intratester and intertester reliability measures were made for this test, as well as studies on the validity of the test, and the results were found to have correlations above .87 .

It has been noted above that the literature over the past several years has indicated the need for screening tests which will assess all three parameters of language: phonology, semantics, and syntax. Until recently only tests which evaluate articulation, a part of phonology, have been available and many such devices have not been practical because of their length or lack of standard procedure. Screening tests axe needed which are fast, reliable, valid, and standardized.

The present study seeks to determine the vaJidity of the OSESST. More specifically, does the screening test effectively identify those children entering school who will probably need speech and/or language intervention? 
CHAPTER III

PROCEDURES

I SUBJECTS

The subjects for this study were forty children from Tillamook County, twenty-one of whom were randomly selected from those who passed the Oregon School Entrance Speech Screening Test (OSESST) and nineteen randomly selected from those who failed. Original plans were to have the children divided equally but sampling procedures resulted in unequal distribution. All subjects were originally screened in June, 1973, by the Tillamook public school speech and hearing staff as a part of the Multi-Modulax Health Examination. During August, 1973, this investigator received the forty subjects in random order and without prior knowledge of which children passed or failed the screening test. The children were from predominantly white middle-class families and had to be six years of age by November 15, 1973, to enter the first grade in the fall of 1973. Random sampling of subjects was accomplished without regard to sex, socioeconomic status, or intelligence. Intelligence was not controlled because the screening test needed to identify all those children with speech and language problems regardless of intellect. Whether or not a child's, communication abilities were appropriate for his mental ability would be deternined later in a diagnostic evaluation. 
Beltone "D Series" audiometers, Models 10 and 12, were used by an audiologist from the Oregon State Health Division to screen children during the Multi-Modular Health Examination in Tillamook County. Each child was tested individually at the frequencies $500,1,000,2,000$, $3,000,4,000$, and $6,000 \mathrm{~Hz}$ respectively, presented through earphones monaurally for each ear at $20 \mathrm{~dB}$. A failure was one "miss" at any frequency. Those who failed the hearing screening were referred for additional hearing tests and speech and language evaluations. Only those children who passed the hearing screening were included in the present study.

\section{INSTRUMENTATION}

Since the present study was designed to validate the screening test, three standardized tests were used to examine the speech and language ability of the subjects. These measures have broad normative data and require little, if any, interpretation in scoring. In addition, scales designed to evaluate voice quality and measure fluency were completed for each child. All tests were administered and scored by the investigator.

The following criteria were utilized to select the tests included in the present investigation:

1. Tests had to be appropxiate for use with six-year-old children.

2. Tests had to assess more thoroughly the same communication skills screened by the OSESST. 
3. Tests, when combined into a battery, could not exceed an overall administration time which the average sixyear-old might tolerate (approximately one hour)。

4. Tests had to Iend themselves to statistical analysis.

The tests which met the foregoing criteria are discussed in some detail below.

Utah Test of Language Development

This test, commonly referred to as the UTID (Mecham et al., 1969, 1973), provides an overall picture of receptive and expressive language skills in both normal and handicapped children (refer to Appendix B). It utilizes the developmental approach for appraisal of language readiness. The items have been selected in part from standardized sources, such as: the Vineland Social Maturity Scale (Doll, 1946); the Peabody Picture Vocabulary Test (Dunn, 1959); the Stanford Binet Intelligence Scale (Terman, 1960); and the Gesell Developmental Schedules (Gesell, 1941).

Instructions for the UTWD recommend that testing begin at approximately the chronological age level of the child. If the child fails to achieve eight consecutive pluses (right answers) above this level, the testing is reversed downward until eight consecutive pluses are achieved; items below that level are assumed to be passed. The basal score is the highest number of consecutive right answers. After a basal has been achieved, items are tested upward until at least eight consecutive minuses (wrong answers) are scored, at which time the test is discontinued as a ceiling has been reached. The total raw score on 
the test is determined by counting the total pluses above the basal score and adding them to the basal score.

A Language Age Equivalent (LAE) is determined from a table (Appendix B) by looking up the total raw score and noting its corresponding IAE. For the purposes of this study those children with an LAE ten months or more below their chronological age were considered as failing the test. This ten-month difference between chronological age and LAE was arbitrarily chosen as a dividing point on a problem/nonproblem continuum. In a study by Beckstead (1972) found in Mecham et al. (1973) a cut-off of twelve months was established for kindergarten children. As the screening test (OSESST) did not want to pass any children with possible speech and language problems (or wanted to err only on the side of false positives), a moxe stringent cut-off point of ten months was established for this study.

\section{Northwestexn Syntax Screening Test}

The NSST (Lee, 1970) may be used to provide a quick estimate of syntactic development as part of a more elaborate speech and language evaluation (Appendix C). It will isolate those children between three and eight years of age who are sufficiently delayed in syntactic development to warrant further study. Although the NSST measures both receptive and expressive use of syntactic forms, only the expressive portion was abninistered in this study. This seemed appropriate since expressive syntax is the only linquistic parameter scored in the OSESST. Administering only half of the NSST does not invalidate the test because receptive and expressive portions are scored independently of each other. 
A normative chart is provided with the test showing the progression of expressive scores from one age group to another for percentiles of $90,75,50,25$, and 10 . Any child whose score is below the 10th percentile warrants further study and consideration for a remedial language training program, unless performance in other language areas is satisfactory. As other language areas are evaluated by the UTLD, all children who scored below the 10 th percentile on the NSST were considered as failing unless their UTLD language score was passing.

\section{Photo Articulation Test}

The PAT (Pendergast et al., 1965) was administered to each subject (Appendix D). All consonant sounds in the initial, medial, and final positions, together with eighteen vowels and diphthongs in the medial position, are evaluated in this test. The subject is asked to name seventy colored photographs and tell a story about a sequence of pictures. Items are grouped to indicate specific areas which may require further examination. After the entire test has been administered, the subject is asked to repeat words from a list of Supplementary Test Words (Appendix D) and to imitate sounds in isolation for all items missed on the PAT. As suggested by Sanders (1970), the normative data concerning age of development of consonant sounds in initial, medial, and final positions presented by Templin (1957) were applied to the PAT. For the purpose of this investigation any errors in the six-yearage range or below constituted a failing score. Errors involving sounds above the child's age range were not considered as failing, but were computed and used in the analysis of results. 


\section{Jewish Hospital Voice Profile}

This profile (JHVP), which describes the various audible characteristics of voice, was completed for each subject (Wilson, 1970). Included is a severity rating from one to seven, one meaning the problem is barely perceptible and seven meaning the problem significantly interferes with communication. A rating also is provided for laryngeal cavity deviations of open and closed vocal folds and abnormal pitch, as well as resonance disorders, rate, intensity, and vocal range (see Appendix E). All problems with a severity rating between three and seven were considered as failing.

Bloodstein's Developmental Phases of Stuttering

The classifications, as described by Luper and Mulder (1964, pp. 20-21.), were applied whenever a fluency disorder was detected by the investigator (see Appendix F). Bloodstein has pointed out that although the development of stuttering is a continual process, certain diagnostic categories provide for a systematic means of evaluating how far a child's problem has progressed. Luper and Mulder have added the descriptive adjectives of "incipient," "transitional," "confirmed," and "advanced" to further describe the four developmental stages. A child exhibiting characteristics described in Phase One, Two, Three or Four was administered the Stuttering Severity Instrument (Riley, 1972). The frequency, duration, and associated physical concomitants of prolongations or repetitions of short speech segments are described by the Riley instrument through a scoring range from zero to forty-five, very mild to very severe. Any child with a severity rating of mild or a 
percentile score above ten failed this portion of the research battery (refer to Appendix G).

\section{INVESTIGATOR RELIABILITY}

This investigator's test administration reliability was examined in a preliminary study. The writer and another experienced speech clinician administered the above tests to six subjects ranging in age from four to six years. Each clinician gave the tests to three of the six children, and scored the tests simultaneously. The correlation of the scores produced a coefficient above the .90 level, which was considered adequate, and all further testing and scoring was done by this investigator.

\section{TESTING ENVIRONMENT}

During August, 1973, forty children were presented to this examiner for testing purposes. The examiner did not know which children had passed or which had failed the screening test administered in June of 1973.

The August evaluations took place with few distractions in a quiet room at the Tillamook County Health Department. In an anteroom, under the supervision of a trained person, each child was instructed to write his name, draw three pictures, such as a house, man, flower, animal, etc., and write numbers from one to thirty if he knew how. Upon completion of this initial task (part of the UTLD), the investigator took the child into the testing room without the parent. The tests and scales were administered in the following order: 1) the articula- 
tion test (PAT); 2) the language test (UTLD); 3) the syntax test (NSST); 4) the voice scale by Wi].son (JHVP); and 5) the fluency classification by Bloodstein and Riley's SSI if needed.

The investigator began the evaluation by praising the child for the written work described above and by asking him some questions about it. The child was then invited to look at the bxightly colored photographs in the articulation test, name each picture, imitate additional words when indicated, and tell what was happening in the story pictures. The language test followed, and by this time rapport was well established for the varied responses required in the language test. The syntax portion was administered quickly and the fluency and voice scales completed. All tests were tallied immediately and rechecked for accuracy later in the day. The investigator returned the child to the waiting room, thanked the parents for their participation and inquired whether or not they had questions or concerns regarding the child's speech and language. The investigator gave the parents a brief report about the test findings and told them that the public school speech clim. nician would contact them after school began regarding intervention if needed.

Each child was seen for approximately forty-five minutes to an hour. All forty children cooperated, willingly answered the questions, and talked freely with the investigator. It is felt that a valid representation of each child's speech and language was obtained during the evaluation. 
V DATA ANAIYSIS

An analysis of OSESST scores and those obtained in the present study was performed. The overall score of each battery, as well as the subtest scores, was compared to find the measure of agreement between the screening test and the longer tests used in this study. Tables were employed to describe the statistical analysis. The tables indicate the number of false negatives, false positives, and scores in agreement in the two batteries of tests. This method of descriptive analysis was felt to be the simplest and most effective method of determining the validity of the screening test. 
CHAPTER IV

RESULTS AND DISCUSSION OF RESULTS

\section{RESULTS}

Results previously obtained from the Oregon School Entrance Speech Screening Test were compared with results from the battery of tests described in Chapter III. Tables were created to numerically describe and compare data from these instruments (refer to Appendix $\mathrm{H}$ for the raw data). These tables display: results of each subject's performance on the OSESST and the tests used in the validity study, and how results compare; number of false negatives, those children with speech and language disorders who were undetected by the OSESST; number of false positives, those children with no speech or language disorders but who were failed by the screening instrument; and those scores from both testing procedures which are in agreement.

\section{Overall Results}

Overall results displayed in Table $I$ are the product of ali subtests in the OSESST and the tests used in the present study. Each subject received an overall score for this table, a pass or a fail for both screening and validity tests. Results shown in Table I answer these specific questions asked in this study: 
1. What are the estimated false negatives, i.e., what proportion of children with speech and language disorders was not detected or was passed by the OSESST?

Results: The OSESST produced six false negatives or 15 percent of those tested.

2. What are the estimated false positives, i.e., what proportion of children without speech and language disorders failed the OSESST?

Results: The OSESST produced four false positives or 10 percent of those tested.

TABLE I

OVERALU TEST RESULTS

\begin{tabular}{|c|c|c|c|}
\hline & \multicolumn{2}{|c|}{$\begin{array}{l}\text { Validity Study } \\
\text { All Tests }\end{array}$} & \multirow[b]{2}{*}{ Subtotal } \\
\hline & Pass & Fail & \\
\hline \multirow{2}{*}{$\begin{array}{l}0 \\
\mathrm{~S} \\
\mathrm{E} \\
\mathrm{S} \\
\mathrm{S} \\
\mathrm{T}\end{array}$} & $\begin{array}{l}\text { Agreed } \\
15\end{array}$ & $\begin{array}{c}\text { False Neg. } \\
6\end{array}$ & 21 \\
\hline & $\begin{array}{c}\text { False Pos. } \\
4\end{array}$ & $\begin{array}{c}\text { Agreed } \\
15\end{array}$ & 19 \\
\hline Subtotal & 19 & 21 & $\begin{array}{c}\text { Total } \\
40\end{array}$ \\
\hline
\end{tabular}


Individual Test Results

Further analyses were conducted to determine correlation between results of the OSESST subtests of articulation, language, syntax, voice, and fluency and results of tests in the validity study. Two-way tables describe and compare those who passed and those who failed. These are not independent tables; hence, a subject may fail more than one test and be a false negative (or a false positive or an agreed score) on one or more tables. Individual false negatives, false positives, and agreed scores do not correlate with overall false negatives, positives, and agreed totals listed in Table I. They only indicate whether the subject passed or failed parallel tests in the OSESST and in the validity study. Articulation Results. Table II reveals that results from the articulation tests produced the greatest variation. Test results from

TABLE II

ARTICULATION TEST RESULTS

\begin{tabular}{|c|c|c|c|}
\hline & \multicolumn{2}{|c|}{$\begin{array}{c}\text { Validity Study } \\
\text { PAT }\end{array}$} & \\
\hline & Pass & Fail & Subtotal \\
\hline $\begin{array}{ll}0 & \\
\mathrm{~S} & \text { Pass }\end{array}$ & $\begin{array}{c}\text { Agreed } \\
24\end{array}$ & $\begin{array}{c}\text { False Neg. } \\
7\end{array}$ & 31 \\
\hline $\begin{array}{l}\mathrm{S} \\
\mathrm{S} \\
\mathrm{T} \quad \text { Fail }\end{array}$ & $\begin{array}{c}\text { False Pos } \\
1\end{array}$ & $\begin{array}{c}\text { Agreed } \\
8\end{array}$ & 9 \\
\hline Subtotal & 25 & 15 & $\begin{array}{c}\text { Total } \\
40\end{array}$ \\
\hline
\end{tabular}


the OSESST and the Photo Articulation Test were in agreement for the twenty-four subjects who passed the articulation tests and eight who failed. Of the remaining eight on which there was disagreement, one was a false positive (i.e., failed by the OSESST and passed by the PAT), and seven were false negatives (i.e., passed by the OSESST and failed by the PAT). Hence, in percentages screening test results revealed 23 percent failed articulation whereas 38 percent failed in the present investigation. This indicates the articulation subtest of the screening test failed to screen out 17.5 percent of articulation disorders.

Language Results. As disclosed by Table III, twenty-seven subjects passed and seven failed the language tests on both the OSESST and the Utah Test of Language Development. There was disagreement on six subjects, four false positives (those failing the screening test and

TABLE III

LANGUAGE TEST RESULTS

\begin{tabular}{|c|c|c|c|}
\hline & \multicolumn{2}{|c|}{$\begin{array}{c}\text { Validity Study } \\
\text { UTID }\end{array}$} & \\
\hline & Pass & Fail & Subtotal \\
\hline \multirow{2}{*}{$\begin{array}{ll}0 & \\
\text { S } & \text { Pass } \\
\text { E } & \\
\text { S } & \\
\text { S } & \\
\text { T } & \end{array}$} & $\begin{array}{c}\text { Agreed } \\
27\end{array}$ & $\begin{array}{c}\text { False Neg. } \\
2\end{array}$ & 29 \\
\hline & $\begin{array}{c}\text { False Pos. } \\
4\end{array}$ & $\begin{array}{c}\text { Agreed } \\
7\end{array}$ & 11 \\
\hline Subtotal & 31 & 9 & $\begin{array}{c}\text { Total } \\
40\end{array}$ \\
\hline
\end{tabular}


passing the UTLD), and two false negatives (those passing the screening test and failing the UTLD). Although the OSESST failed a larger percentage of subjects than the UTLD (28 percent versus 23 percent), the language portion of the screening test still failed to identify 5 percent of language problems.

Syntax Results. Table IV gives data based upon syntactic analysis. There were no failures on the syntax subtest of the OSESST but four subjects or 10 percent failed the Northwestern Syntax Screening Test criteria. These stated the child must fail the language test (UTLD) and the syntax test (NSST) to fail syntax in this study. If NSST results are considered without UTLD scores, there were nine false

TABLE IV

SYNTAX TEST RESULTS

\begin{tabular}{|c|c|c|c|}
\hline & \multicolumn{2}{|c|}{$\begin{array}{l}\text { Validity Study } \\
\text { NSST and UTLD }\end{array}$} & \\
\hline & Pass & Fail & Subtotal \\
\hline $\begin{array}{ll}0 & \\
\text { S } & \text { Pass } \\
\text { E } & \end{array}$ & $\begin{array}{l}\text { Agreed } \\
36 \quad(31) *\end{array}$ & $\begin{array}{l}\text { False Neg. } \\
\qquad \begin{array}{l}4 \\
\end{array}\end{array}$ & 40 \\
\hline $\begin{array}{ll}\mathrm{S} & \\
\mathrm{T} & \\
& \text { Fail }\end{array}$ & $\begin{array}{c}\text { False Pos. } \\
0\end{array}$ & $\begin{array}{c}\text { Agreed } \\
0\end{array}$ & 0 \\
\hline Subtotal & $36 \quad(31) *$ & $(9) *$ & $\begin{array}{c}\text { Total } \\
40\end{array}$ \\
\hline
\end{tabular}

*NSST only 
negatives, rather than four. These data indicate the syntax subtest of the OSESST does not effectively identify those children whose syntactic competence should be more thoroughly evaluated.

Voice Results. Based on a population of forty subjects the OSESST effectively accomplishes its screening purpose in the area of voice disorders. Analysis of voice results revealed complete agreement. Both the screening test and the Jewish Hospital Voice Profile failed the same three subjects, or 8 percent of the population tested (refer to Table v).

TABLE V

VOICE EVALUATION RESULTS

\begin{tabular}{|c|c|c|c|}
\hline & \multicolumn{2}{|c|}{$\begin{array}{c}\text { Validity Study } \\
\text { JHVP }\end{array}$} & \multirow[b]{2}{*}{ Subtotal } \\
\hline & Pass & Fail & \\
\hline $\begin{array}{ll}0 & \\
\text { S } & \text { Pass }\end{array}$ & $\begin{array}{l}\text { Agreed } \\
\quad 37\end{array}$ & $\begin{array}{c}\text { False Neg. } \\
0\end{array}$ & 37 \\
\hline $\begin{array}{ll} & \\
\mathrm{S} & \\
\mathrm{T} & \end{array}$ & $\begin{array}{c}\text { False Pos. } \\
0\end{array}$ & $\begin{array}{c}\text { Agreed } \\
3\end{array}$ & 3 \\
\hline Subtotal & 37 & 3 & $\begin{array}{c}\text { Total } \\
40\end{array}$ \\
\hline
\end{tabular}

Fluency Results. Table VI shows no child was failed for a rhythm disorder by the OSESST or the longer instruments employed in the validity study (Bloodstein's Developmental Phases of Stuttering and the 
TABLE VI

FLUENCY EVALUATION RESULTS

\begin{tabular}{|c|c|c|c|}
\hline & \multicolumn{2}{|c|}{$\begin{array}{l}\text { Validity Study } \\
\text { Bloodstein's Developmental Phases }\end{array}$} & \multirow[b]{2}{*}{ Subtotal } \\
\hline & Pass & Fail & \\
\hline $\begin{array}{ll}\mathbf{0} & \\
\mathrm{S} & \text { Pass }\end{array}$ & $\begin{array}{l}\text { Agreed } \\
\quad 40\end{array}$ & $\begin{array}{c}\text { False Neg. } \\
0\end{array}$ & 40 \\
\hline $\begin{array}{ll}\text { S } & \\
\text { T } & \\
& \text { Fail }\end{array}$ & $\begin{array}{c}\text { False Pos. } \\
0\end{array}$ & $\begin{array}{c}\text { Agreed } \\
0\end{array}$ & 0 \\
\hline Subtotal & 40 & 0 & $\begin{array}{c}\text { Total } \\
40\end{array}$ \\
\hline
\end{tabular}

Stuttering Severity Instrument).

Consolidated Test Results

Table VII consolidates each subject's results on both the OSESST and the instruments used in the validity study, gives each child's performance on all tests, and compares results of the OSESST and the validity tests. Numbers listed in the far right column and in parentheses next to screening subtests under the heading OSESST Subtotals are results of the forty subjects tested by the screening test. Results of tests in this study are found in the bottom row marked Validity subtotals. Individual results compared in the center of Table VII are discussed below. 
TABLE VII

CONSOLIDATED RESULTS OF THE OSESST

AND THE VALIDITY STUDY

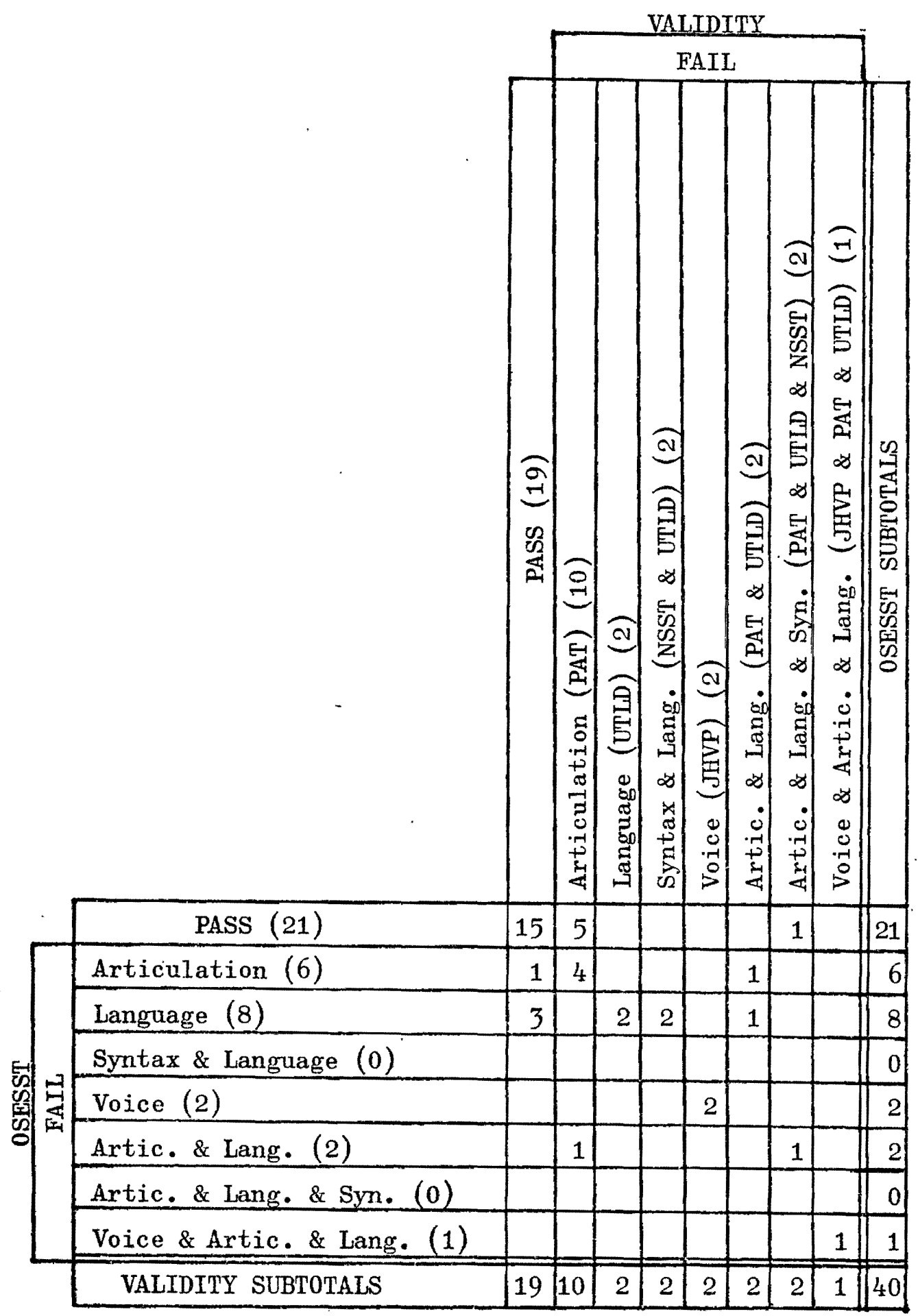


Pass. The first row in Table VII shows twenty-one subjects passed all OSESST subtests. Fifteen passed all validity tests in this investigation, five failed the articulation test (PAT), and one the articulation, language (UTLD), and syntax (NSST) tests.

Articulation. The second row shows that six subjects failed the articulation subtest in the 0SESST. Of these six, one passed all tests, four failed the articulation test (PAT), and one failed the articulation and language tests (PAT and UTWD) in this investigation.

Language. In the language portion of the OSESST were eight failures. During this investigation three of the eight passed all tests, one failed both the articulation and language tests (PAT and UTLD), two the language test (UTLD), and two the language and syntax tests (UTLD and NSST).

Syntax and Language. Under syntax and language Table VII shows that the OSESST failed no one for syntax alone or syntax and language. Syntax is not listed as a separate category because neither the screening test nor the NSST failed subjects for syntax only.

Voice. Both the OSESST and the present validity study agreed on the three subjects who failed voice. The validity study utilized the Jewish Hospital Voice Profile.

Articulation and Language. These two areas were failed by two subjects in the screening test. One failed articulation only, the other articulation, language, and syntax.

Articulation, Language, and Syntax. The screening test failed no one on all three of these tests. Two subjects failed the PAT, the UTLD, and the NSST in the present study. 
Voice, Articulation, and Language. The final row in Table VII reveals the last subject failed voice, articulation, and language on the OSESST and the tests used in the present study.

\section{DISCUSSION OF RESULTS}

Overall Results.

This study sought to determine if the OSESST effectively identified those children entering first grade in Tillamook County who were in need of diagnostic testing and possible treatment. 0verall results cited in the foregoing section indicate screening test results disagreed with the present study on ten of the forty children studied (25 percent).

False Positives. Four of the children needed further testing by the OSESST, yet were considered normal when the validity tests were administered. These four subjects were false positives: those identified as having speech and language problems within normal limits according to this study. Three of these children failed the language screening subtest and one failed the articulation portion of the screening.

The three language false positives missed the question: "How are a bird and a dog different?" and one also missed: "What do you do when you're thirsty?" These three subjects passed the language test (UTD) but their Language-Age-Equivalent scores were two to eight months below their chronological ages.

The subject failing the articulation portion of the screening test erred on the $/ r /$ sound and $/ 1 / b l$ ends, both of which were scored correct on the PAT. 
False Negatives. The six subjects passing the screening test yet failing the validity tests were of the most concern in this study. Five subjects had mild articulation errors undetected by the screening test, and the sixth failed because of language, syntax, and a mild articulation error.

Four of the six articulation errors were omissions of the final $/ 1 /$ sound. Another was an $/ r /$ distortion of mild to moderate severity in the initial, medial, and final positions, and the last a distorted $/ f /$ associated with tongue thrusting behavior. In this last case the OSESST showed the child failed the $/ \mathrm{s} /$ and $/ \mathrm{z} /$ sounds (as did the PAT) but not the $/ \mathrm{f} /$. Consequently, the subject was passed in the screening because /s/ and /z/ are seven-year sounds developmentally.

According to Templin (1957) and Poole (1934), the final/1/ sound, which was the most frequent false negative (four of the six), is considered one of the later developing sounds at the six-year level. Poole maintains the final $/ 1 /$ is not used by 100 percent of six-yearolds until later in their sixth year. Children omitting the final / $/$ in this study ranged in age from 6.0 to 6.3 years and perhaps had not as yet developed the sound.

Blakeley (1973) maintains the $/ 1 /, / r /$, and $/ f /$ sounds usually are not worked on until after the first grade. If these sounds are inconsistent, slightly distorted, or if the child has only mild difficulty with them, Blakeley recommends leaving these sounds until the third or fourth grades.

Although 0SESST results did not identify all children who should have failed according to its criteria (based on Templin norms, 1957), 
perhaps the criteria of the articulation screening subtest and the PAT are too stringent for children entering school.

The one subject who failed the language, syntax, and articulation tests but passed the screening subtests is difficult to understand. This subject's Language Age Equivalent on the UTLD was eighteen months behind his chronological age and the syntax score on the NSST was below the 10 th percentile. In the syntax test pluralization and tense markers were incorrect and in the language test the subject failed four out of eight four- to five-year-old items.

Individual Test Results

Articulation. Another purpose of this study was to determine whether or not individual test scores were consistent in both studies. When articulation results of both tests were compared, one false positive and seven false negatives were found. The false positive consisted of distorted $/ \mathrm{r} /$ and $/ 1 /$ blends, which in the later test appeared normal. The false negatives were caused by mild and/or subtle articulation errors: one $/ / /$ distortion with tongue thrusting behavior; four final / $/$ omissions; one distorted / $r$ in all positions (initial, medial, and final); and one / $/$ and /d/ distortion accompanied by tongue thrusting.

The disparity of results between the OSESST and the Photo Articulation Test may be due to many factors. Winitz (1969) cites several potential sources of variability in articulation testing, grouped as follows: 
1. Variance attributable to the subjects tested.

2. Variance attributable to the examiner.

3. Variance attributable to the test instrument.

4. Variance attributable to subject-examiner interaction.

The first source of variability involves variation in the subject's performance. Temporal reliability, according to Winitz, is another name for subject variance, which has been examined in a number of studies. If the interval between tests is small and training is not introduced, variation should be minimal. Winitz (1963) conducted a study involving 100 kindergarten children. For the $/ 1 /$ sound, 21 percent of those tested altered their response (correct to incorrect and incorrect to correct). The subjects were tested on two occasions with an interval of one week between test sessions. Considerable intrasubject variability was noted for this sound, and perhaps this may account for the variability regarding the $/ 1 /$ sound between the OSESST and the PAT. The two months' interval between administration of the OSESST and the PAT also may account for the false positives, those failing the screening test but passing the validity test.

The second factor causing variability may be attributed to the examiner. The usefulness of an articulation test score depends, in part, upon the examiner's accuracy and reliability. Henderson (1937) found that in a live articulation testing situation where a simple right versus wrong judgement was made for each response, judges agreed 80 percent in their scoring of responses. When judges were required to agree on the type of exror they had scored, agreement dropped to 72 percent. 
Since the present investigation compared right versus wrong judgement of articulation errors, it should have fairly high interexaminer reliability.

A third variance in articulation testing is due to the test instrument. Some, such as the PAT, use the spontaneous method of eliciting speech; others utilize the imitative method, as in the OSESST. Templin (1947) concluded that stimulus presentation was not an important variable in articulation testing. Snow and Milisen (1954), on the other hand, found the imitative method elicited more correct responses than the spontaneous method. Carter and Buck (1958), Smith and Ainsworth (1967), and Kresheck and Socolofsky (1972) support the Snow and Milisen findings. The articulation errors causing false negatives in this study could be due to the fact that this investigator tested each sound by listening to the spontaneous naming of pictures while the screening examiners asked the children to imitate the words. Since the child had been previously judged to misarticulate the sound during the spontaneous response, perhaps this investigator was "cued" to listen for faulty articulation during the imitative responses.

The test instrument produces another source of variability, that is, the units or words selected as stimuli. A sound may be adequately produced in one word and not in another. According to Winitz, evidence as to the importance of the words selected as stimuli is limited. Even so, the PAT helps eliminate this variable because all sounds misarticulated in the spontaneous portion are tested in three additional words. Lastly, articulation testing may be affected by subject-examiner interaction. Siegel (1962) reports data suggesting that examiners 
differed in responses they evoked from children, rather than in the way they scored responses. Winitz (1969) writes:

In any situation in which two or more persons are assembled, even where one is a "subject" and the other "examiner," the nature of the assembly itself may affect the behavior of each of the individuals.

Thus, discrepancy in scores of the OSESST and the PAT may be partially due to subject-examiner interaction.

Although the proportion of false negatives due to the OSESST articulation subtest seems high (17 percent) for a screening device, errors undetected were mild in degree. One might hypothesize that had there been a severity criterion established in the present investigation, some or all false negatives might have been eliminated in the articulation section.

Language. The UTLD was administered to each child during the present study. Analysis of this test and the language subtest of the OSESST produced four false positives and two false negatives. The false positives were caused when subjects answered items incorrectly on the screening test, thus causing them to fail the screening. The question "How are a bird and a dog different?" was answered incorrectly by three of the four subjects. One also missed "What do you do when you're thirsty?" The fourth false positive did not follow directions involving the prepositions "in front" and "next to." Although these subjects passed the NSST and the UTLD, their Language-Age-Equivalent scores were all two to four months behind their chronological ages. One of the two language false negative scores was discussed earlier in overall results. This subject had an LAE score eighteen months 
behind his chronological age, and could not copy a cross, name colors, repeat four digits, or repeat a țelve-syllable sentence. The other language false negative failed articulation on the screening test but did not fail language. According to the LAE score, this child was fourteen months delayed in language. His errors involved auditory memory, vocabulary, and general knowledge. Since these subjects were over a year delayed in language skills, the screening instrument should have identified them as needing further diagnostic testing.

Syntax. This subtest produced interesting results. The screening test failed no one for syntax; yet the NSST failed four subjects who not only failed the NSST but also met the present study's criteria for failing the UTLD. If the,NSST were considered alone, there would have been nine instead of four false negatives. Many reasons could be advanced for these false negatives. For instance, in a three-to-five-minute screening test there may not be time to elicit five spontaneous sentences from the subject, determine their mean length of response (MLR), and evaluate the presence of various parts of speech. Both McCarthy (1930) and Johnson et al. (1963) state that a minimum of sixty responses must be obtained for a valid MLR. McCarthy (1930) called MLR "The simplest and most objective measure of the degree to which children combine words at the various ages," and said it is a reliable measure of linguistic maturity. However, McCarthy does not mention using MLR to measure syntactical ability specifically nor does she state syntax must be correct in responses measured. Templin (1957) reports norms showing the relative incidence of various parts of speech. Three parts of speech are used in the OSESST to measure syntactical ability: preposi- 
tions, pronouns, and conjunctions. According to Templin, three-year-old children use these language elements almost as often as eight-year-olds. Thus, it is questionable whether presence of these parts of speech is a valid measure of syntactical competence in a six-year-old child.

Menyuk (1971) reports on the use of plurals, the fourth item evaluated in the OSESST syntax subtest. She states that rules for pluralization are acquired between the ages of three to seven years. At the six-year level children do not usually omit plurals; instead, they use them redundantly.

It seems that the five spontaneous sentences and the four parts of speech required by the OSESST do not indicate the child's level of language ability, particularly his syntactical ability.

Voice. Results from these tests agree completely. Both the screening test and the present investigation failed three subjects. This examiner used the JHVP to evaluate each subject. Those with a severity rating three or above were referred for further testing. After data for this study had been collected, this examiner learned that the speech clinicians in Tillamook County administering the OSESST also had been trained to use the Wilson evaluation method. Although they did not complete a scale for each person (examiners simply indicated a pass or fail for voice), their training in this method may have been responsible for the 100 percent agreement.

Fluency. One hundred percent agreement was found in fluency subtest results. Since neither the screening test nor the present study identified children with rhythm disorders, it might be assumed that either there were no children with fluency disorders or that neither 
test adequately evaluated fluency. West and Ansberry (1968) suggest that children with fluency disorders should be referred for speech help by the classroom teacher, counselor, parent, or other sources, as a screening often does not elicit an adequate sample of speech by which to effectively evaluate fluency. 
CHAPTER V

SUMMARY AND IMPLICATIONS

I STMMARY

This study was designed to validate a speech screening device entitled the Oregon School Entrance Speech Screening Test. The 0SESST was developed to identify quickly those children entering first grade who are in need of speech and language intervention. The present study sought to determine what proportion of children with speech and language disorders was not detected by the screening test and what proportion of children without speech and language disorders failed the 0SESST. In addition, this study undertook to determine whether results of this investigation are consistent with those obtained on the 0SESST in areas of articulation, syntax, language reception and expression, voice, and speech fluency.

Subjects for this investigation were forty children just entering first grade in Tillamook County. Twenty-one were randomly selected from those who passed the screening test and nineteen from those who failed. This investigator received the forty subjects in random order and without prior knowledge of which children passed or failed the screening test.

Three standardized tests were used to evaluate the speech and language of the subjects: the Photo Articulation Test (Pendergast et al., 1965), the Utah Test of Language Development (Mecham et al., 1969), 
and the Northwestern Syntax Screening Test (Lee, 1970). The Jewish Hospital Voice Profile (Wilson, 1970) was completed for each subject to assess, the parameters of voice. Bloodstein's Developmental Phases of Stuttering (Luper and Mulder, 1964) and the Stuttering Severity Instrument (Riley, 1972) were utilized to assess rhythm disorders.

Results of tests used in the validity study were compared with results of the screening test. Analysis showed the OSESST produced six false negatives, or 15 percent of those tested passed the screening test but failed the validity tests. Four false positives or 10 percent of the subjects failed the OSESST and passed the validity tests. Analysis of individual tests revealed that all the OSESST subtests except voice and fluency produced false positives and false negatirves. Voice subtests, as well as fluency subtests, produced 100 percent agreement. The largest amount of false negatives was produced in the articulation test. These errors, however, were all mild in severity and would not be treated by most speech clinicians. The two language and syntax false negatives were of more concern. These subjects, which were delayed in language skills by more than one year, should have been detected by the screening test. Fortunately, only one subject passed the entire screening test with moderate to severe problems. Additional subjects, although undetected by certain parts of the OSESST, were failed in another area. Thus, the four who should have failed syntax but did not, failed language or articulation and were identified for further diagnostic testing and possible intervention. 


\section{IMPLICATIONS}

\section{Future Application}

For the most part the OSESST articulation subtest is a valid test. If all mild articulation errors are to be detected, however, the method of adninistering the subtest must be changed so that sounds irequently misarticulated at or below the six-year-level are tested by the spontaneous method; the $/ 1 /, / r /$, and $/ / /$ will thus be elicited from the child by asking him to name pictures or objects.

This investigator believes that the language subtest, which in this investigation successfully identified most of the children with language disorders, is a fairly valid indicator of children's language abilities. One change, however, should be made in the criteria for this subtest relative to body parts: the subject should fail if he misses two out of eight body parts, rather than three out of eight. Had this criterion been applied in the OSESST, the screening test would have identified the subject with an LAE score fourteen months below his chronological age as needing further diagnostic testing. Another false negative with an LAE score eighteen months delayed did not fail the screening test, and the investigator feels this was due to examiner error, and was not the fault of OSESST.

The weakest OSESST subtest is the one utilized to assess syntax and should be replaced as it does not screen out children with syntactical disorders. Using a five-sentence spontaneous language sample to evaluate syntax appears invalid; other methods should be investigated. McNeill (1966), Ervin-Tripp (1964), Menyuk (1971), and Fluharty (1974) defend using sentence imitation tasks as a measure of expressive language 
performance, and report that the child's underlying knowledge of grammatical rules can be assessed by his ability to imitate sentences incorporating various structures. Thus, sentences involving both morphologic and syntactic structures appearing in the child's speech by six years of age might replace the present syntax portion of the OSESST.

Until research satisfactorily demonstrates that a sample of five sentences validly represents the child's language ability, mean length of response should not be determined.

If the complete syntax portion of the test is not replaced, then directions to the examiner must be changed. Not only should the clinician determine whether plurals, pronouns, articles, and conjunctions are appearing in the child's speech, but he also should evaluate their correct usage.

Voice and fluency subtests of the OSESST appear to adequately measure that which they purport to measure and, hence, need not be changed. This investigator recommends, however, that before giving the screening test, all examiners be trained to administer the Jewish Hospital Voice Profile.

Euture Research

Research is needed to discover which syntactic structures best evaluate a child's linguistic competence, and a study to this end should be undertaken. For example, various combinations of sentences incorporating syntactic structures appropriate for six-year-olds might be selected and administered, together with the NSST. Then results could be compared to determine whether such combinations screen out those chil- 
dren likely to fail the NSST and, therefore, in need of further testing and probable intervention.

After the above changes are made, the OSESST should be revalidated and administered to another forty or more children within two weeks of screening, rather than two months as in the present study. For quality control, routine monitoring of the screening process should be completed each year. A complete battery of tests, as used in this investigation, might be administered to a few children randomly selected from each group screened. Then results from the 0SESST and the battery of tests could be compared to determine whether the screening test is identifying those children in need of further testing.

This study was undertaken to determine the validity of the OSESST. The voice and fluency subtests were found to be valid measures. The investigator, however, recommended modifications for the articulation and language portions, and suggested that the syntax subtest be replaced as it did not identify those children with syntactical problems. 
R E F E R E C E S 


\section{REFERENCES}

Ainsworth, S., Speech Correction Methods. Englewood Cliffs, N.J.: Prentice Hall (1948).

Anderson, C. L., School Health Practice. St. Louis, Mo.: C. V. Mosby Co. (1972).

Beckstead, M. G., Determining Discrimination Power of Selected Items on the Utah Test of Language Development for Establishment of Efficiency in Potential Screening Procedures. Unpublished Master's thesis, University of Utah (1972).

Bellugi-Klima, U., Evaluating the Child's Language Competence. Washington, D.C.: ERIC Microfilm (1968).

Black, Martha E., Speech Correction in the Schools. Englewood Cliffs, N.J.: Prentice Hall, Inc. (1964).

Blakeley, R. W., The Practice of Speech Pathology. Springfield, Ill.: Charles C. Thomas (1972).

Bryngelson, B., and Glaspey, E., Speech in the Classroom (With Speech Improvement Cards). Chicago, Ill.: Scott (1962).

Carter, E. T., and Buck, M. W., "Prognostic Testing for Functional Articulation Disorders Among Children in the First Grade." Speech and Hearing Dis., 23, 124-133 (1958).

Dickson, S., and Jann, G. R., "Diagnostic Principles and Procedures." In Stanley Dickson (Ed.), Communication Disorders, Remedial Principles and Practices. Glenview, Ill.: Scott, Foresman and Co. $(1974)$.

Diehl, C., and Stinnett, L., "Efficiency of Teacher Referrals in a School Speech T'esting Program." J. Speech and Hearing Dis., 22, 113-117 (1956).

Doll, E. A., The Vineland Social Maturity Scale. Minneapolis: American Guidance Service (1959).

Drumwright, A., Van Natta, P., Camp, B., Frankenburg, Wm., and Drexler, H., "The Denver Articulation Screening Test." J. Speech and Hearing Dis., 38, 3-14 (1973). 
Dunn, L. J., Peabody Picture Vocabulary Test. Minneapolis: American Guidance Service (1959).

Eisenson, J., and 0gilvie, M., Speech Correction in the Schools (3rd ed.). New York: Macmilian (1971).

Ervin-Tripp, S. M., "Imitation and Structural Changes in Children's Language." In E. H. Lennenberg (Ed.), New Directions in the Study of Language. Cambridge: M.T.T. Press (1964).

Fluharty, Nancy Buono, "The Design and Standardization of a Speech and Language Screening Test for Use with Pre-school Children." J. Speech and Hearing Dis., 39, 75-88 (1974).

Gesell, A. L., and Amtruda, D. S., Developmental Diagnosis. New York: Hoeber (1941).

Henderson, F. M., "Accuracy in Testing the Articulation of Speech Sounds." J. of Educational Res., 31, 348-356 (1938).

Henja, R., Henja Developmental Articulation Test. Madison, Wis.: College Printing and Typing (1955).

Irwin, Ruth Becky, Speech and Hearing Therapy. Pittsburgh: Stanwix House (1965).

Johnson, W., Darley, F. L., and Spriesterbach, D. C., Diagnostic Methods in Speech Pathology. New York: Harper and Row (1963).

Johnson, W., et al., Speech Handicapped School Children. New York: Harper and Row (1967).

Kirk, S. A., McCarthy, J. J., and Kirk, W. D., Illinois Test of Psycholinguistic Abilities. Urbana, Ill.: University of Illinois Press (1968).

Kresheck, J. D., "Imitative and Spontaneous Articulatory Assessment of Four-Year-0ld Children." J. Speech and Hearing Res., 15, 729-733 (1972).

Lee, L., Northwestern Syntax Screening Test. Evanston, I11.: Northwestern University Press (1971).

Luper, H. L., and Malder, R. L., Stuttering Therapy for Children. Englewood Cliffs, N.J.: Prentice Hall (1964).

McCarthy, Dorothea, "Language Development in Children." In Leonard Carmichael (Ed.), Manual of Child Psychology. New York: Wiley (1954). 
McCarthy, Dorothea, "The Language Development of the Preschool Child." Child Welfare Monogr. 4. Minneapolis: University of Minnesota Press, 122-130 (1930).

McNeil1, David, "Developmental Psycholinguistics." In Frank Smith and P. Miller (Eds.), The Genesis of Language. Cambridge: M.I.T. Press (1966).

Mecham, M., et al., "Use of the Utah Test of Language Development for Screening Language Disabilities." J. Learning Disabilities, 6, No. $7,65-68$ (1973).

Mecham, M., Jex, J. L., and Jones, D., Utah Test of Language Development. Salt Lake City, Utah: Communications Research Institute (1967).

Menyuk, P., The Acquisition and Development of Language. Englewood Cliffs, N.J.: Prentice-Hall Inc. (1971).

Monsees, E., and Berman, C., "Speech and Language Screening in a Summer Headstart Program." J. Speech and Hearing Dis., 33, 121-126 (1968).

Montgomery, J., Look and Say Cards. Chicago, I1l.: King Co. (1960).

Nichols, A. C., "Public School Speech and Hearing Therapy." In R. W. Rieber and R. S. Brubaker (Eds.), Speech Pathology. Amsterdam: North Holland Publishing Co. (1966).

Pendergast, K., "Speech Improvement and Speech Therapy in the Elementary School." ASHA, 5, 548-549 (1963).

Pendergast, K., et al., Photo Articulation Test. Chicago, Ill.: The King Co. (1965).

Perkins, W. H., Speech Pathology: An Applied Behavioral Science. St. Louis, Mo.: C. V. Mosby Co. (1971).

Poole, I., "Genetic Development of Articulation of Consonant Sounds in Speech." El ementary English Review, 11, 159-161 (1934).

Prahl, Harriet M., and Cooper, B., "Accuracy of Teacher Referral of Speech Handicapped Children." ASHA, 6, 393 (1964).

Pronovost, W., "Case Selection in the Schools: Articulatory Disorders." language Speech and Hearing Services in Schools. Washington, D.C.: American Speech and Hearing Association, 1, 17-23 (1970).

Sanders, L. J., Procedure Guides for Evaluation of Speech and Language Disorders in Children. Danville, IIl.: The Interstate Printers and Publishers, Inc. (1972). 
Smith, M. W., and Ainsworth, S., "The Effects of Three Types of Stimulation on Articulatory Responses of Speech Defective Children." J. Speech and Hearing Res., 10, 348-353 (1967).

Snow, K., and Milisen, R., "The Influence of Oral Versus Pictorial Presentation upon Articulation Testing Results." J. Speech and Hearing Dis. Monogr. Suppl. 4, 29-36 (1954).

Sommers, Ronald K., "Case Finding, Case Selection, and Case Load." In Ronald van Hattum (Ed.), Clinical Speech in the Schools. Springfield, Ill.: Charles C. Thomas (1969).

Terman, L. M., and Merrill, M. A., Measuring Intelligence. Boston: Houghton-Mifflin (1937).

Terman, L. M., and Merrill, Maude A., A Stanford Binet Intelligence Scale. Boston: Houghton-Mifflin (1960).

Templin, M., Certain Language Skills in Children. Minneapolis: University of Minneapolis Press (1957).

Templin, M., and Darley, F. L., The Templin-Darley Tests of Articulation (2nd ed.). Iowa City: University of Iowa (1969).

Van Riper, C., Speech Correction: Principles and Methods (4th ed.). Englewood Cliffs, N.J.: Prentice Hall, Inc. (1963).

Wechsler, D., Wechsler Intelligence Scale for Children. New York: Psychological Corporation (1949).

West, Robert, and Ansberry, Merle, The Rehabilitation of Speech (4th ed.). New York: Harper and Row (1968).

Wilson, Frank B., "The Voice-Disordered Child: A Descriptive Approach." Language Speech and Hearing Services in Schools. Washington, D.C.: American Speech and Hearing Association, 4, 13-18 (1970).

Winitz, Harris, Articulatory Acquisition and Behavior. New York: Appleton-Century-Crofts (1969). 
A P P E N D I C E S 
APPENDIX A

OREGON SCHOOL ENTRANCE SPEECH SCREENING TEST

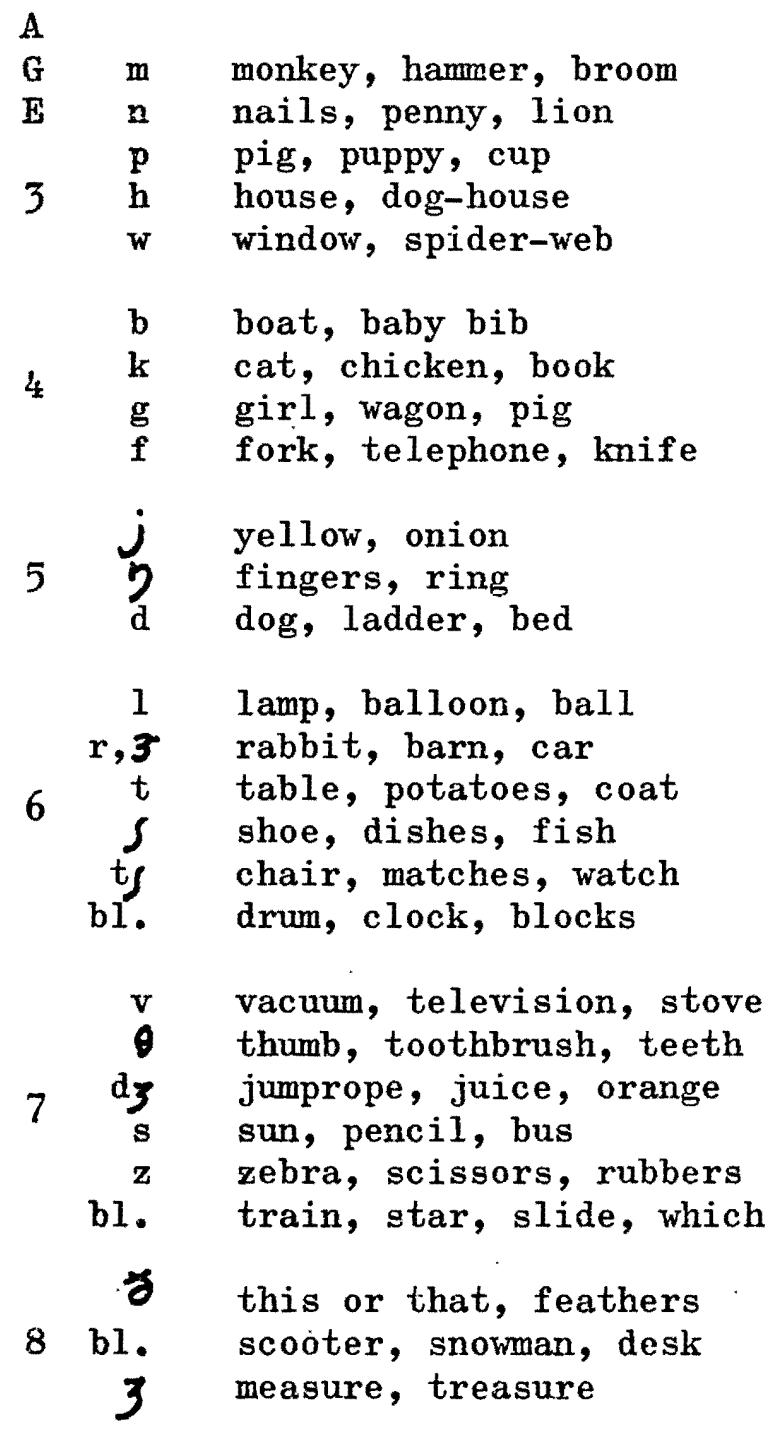


OSESST - Cont.

\section{Syntax}

Use the following questions as needed:

Do you have a pet? What kind? (or, What kind of pet would you like to have?) What does he look like? And/or, Did you ever hurt yourself? Where? How did it happen? What did you do?

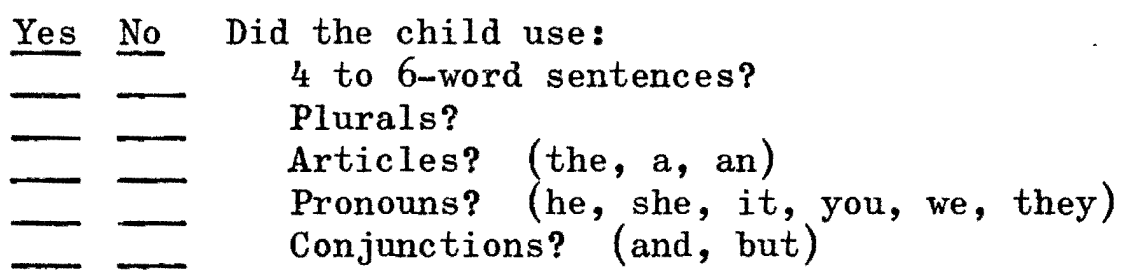

Language Reception

5 out of 5 .

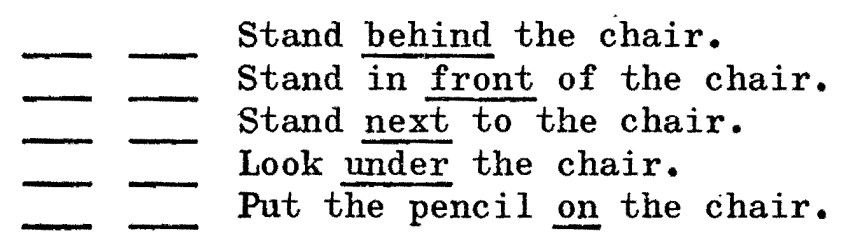

\section{Language Expression}

Body Parts: 6 out of 8 is passing.

What is this called? (Point to:)

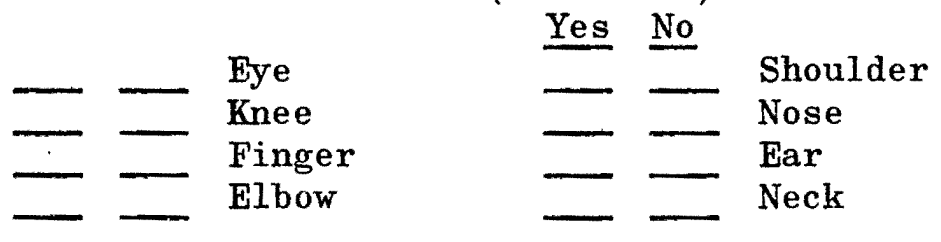

Color Concepts: 6 out of 8 .

What color is this? (Present colored strips.)

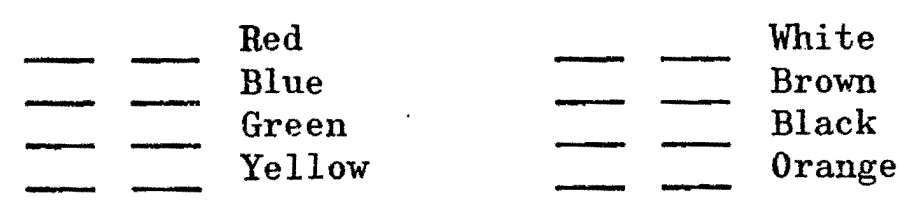


OSESST - Cont.

Language Expression - Cont.

General Knowledge: 5 out of 5 .

Yes No

Which is bigger, a tree or flower?

- What do you do when you're thirsty?

- What is a stove for?

W What are houses made of?

- - How are a bird and a dog different? 
APPENDIX B

UTAH TEST OF LANGUAGE DEVELOPMENT

\section{I - II Years}

1. Responds to name and 'no-no.'

2. Follows simple instructions.

3. Marks with pencil or crayon.

4. Recognizes names of common objects.

5. Recognizes parts of body when named.

6. Recognizes parts of body (cont.).

7. Identifies common pictures when named.

8. Word combinations of two or more.

II - III Years

9. Names common pictures.

10. Names common pictures (cont.).

11. Can repeat two digits.

12. Responds to simple commands.

13. Identifies action in pictures.

14. Names one color.

15. Receptive vocabulary.

III - IV Years

16. Can repeat three digits.

17. Says full name.

18. Names common pictures.

19. Says at least one nursery rhyme.

20. Can copy cross.

IV - V Years

21. Names colors.

22. Can repeat four digits.

23. Carries out three commissions.

24. Can repeat a twelve-syllable sentence.

25. Draws with pencil or crayon.

V - VI Years

26. Can copy a square.

27. Prints simple words.

28. Receptive vocabulary. 
UTLD - Cont.

VI - VII Years

29. Names penny, nickel, and dime.

30. Writes numbers to the thirties.

31. Can tell a familiar story.

32. Reads words on pre-primer level.

33. Recites numbers from one to fifty.

34. Can copy a diamond.

VII - VIII Years

35. Receptive vocabulary.

36. Names quarter, half-dollar, and dollar.

37. Can repeat five digits.

38. Can name the days of the week.

VIII - X Years

39. Can repeat 16 syllable sentence.

40. Can write cursively with pencil.

41. Can rhyme words.

42. Can repeat 4 digits reversed.

43. Receptive vocabulary.

$\mathrm{X}-\mathrm{XV}$ Years

44. Can repeat 6 digits.

45. Can repeat a 20 syllable sentence.

46. Can repeat 5 digits reversed.

47. Receptive vocabulary.

48. Can repeat 5 mono-syllable words.

49. Can repeat difficult sentence from memory.

50. Receptive vocabulary.

51. Is oriented on directions.

COMMENTS: 
UTLD - Cont.

TABLE FOR CONVERTING TOTAL RAW SCORES TO LANGUAGE-AGE-EQUIVALENTS

(In years and months)

\begin{tabular}{|c|c|c|c|c|c|}
\hline $\begin{array}{l}\text { Raw } \\
\text { Score }\end{array}$ & $\begin{array}{c}\text { Language } \\
\text { Age }\end{array}$ & $\begin{array}{l}\text { Raw } \\
\text { Score }\end{array}$ & $\begin{array}{c}\text { Language } \\
\text { Age }\end{array}$ & $\begin{array}{l}\text { Raw } \\
\text { Score }\end{array}$ & $\begin{array}{c}\text { Language } \\
\text { Age }\end{array}$ \\
\hline 1 & $0-9$ & 18 & $3-5$ & 35 & $7-1$ \\
\hline 2 & $1-1$ & 19 & $3-8$ & 36 & $7-3$ \\
\hline 3 & $1-4$ & 20 & $3-10$ & 37 & $7-7$ \\
\hline 4 & $1-6$ & 21 & $4-1$ & 38 & $7-11$ \\
\hline 5 & $1-7$ & 22 & $4-4$ & 39 & $8-3$ \\
\hline 6 & $1-9$ & 23 & $4-7$ & 40 & $8-8$ \\
\hline 7 & $1-10$ & 24 & $4-9$ & 41 & $9-0$ \\
\hline 8 & $2-0$ & 25 & 5-0 & 42 & $9-5$ \\
\hline 9 & $2-2$ & 26 & $5-3$ & 43 & $9-11$ \\
\hline 10 & $2-3$ & 27 & 5-6 & 44 & $10-5$ \\
\hline 11 & $2-5$ & 28 & $5-10$ & 45 & $10-11$ \\
\hline 12 & $2-6$ & 29 & $6-1$ & 46 & $12-0$ \\
\hline 13 & $2-8$ & 30 & $6-3$ & 47 & $12-7$ \\
\hline 14 & $2-9$ & 31 & $6-5$ & 48 & $13-5$ \\
\hline 15 & $2-11$ & 32 & $6-6$ & 49 & $14-6$ \\
\hline 16 & $3-1$ & 33 & $6-8$ & 50 & $15-4$ \\
\hline 17 & $3-3$ & 34 & $6-11$ & 51 & $16-0$ \\
\hline
\end{tabular}




\section{APPENDTX C}

NORTHWESTERN SYNTAX SCREENING TEST

\section{Expressive}

1. The baby is sleeping.*

The baby is not sleeping.

2. The dog is on the box.

The $\operatorname{dog}$ is in the box.*

3. She sees the car.*

He sees the car.

4. The cat is behind the desk. The cat is under the desk.*

5. The boy pulls the girl. The girl pulls the boy.*

6. The fish is swimming.* The fish are swimming.

7. The girl sees the dog. The girl sees the dogs.*

8. This is their wagon.* This is his wagon.

9. The cats play. The cat plays.*

10. Mother says, "Where is that boy?"* Mother says, "Who is that boy?"

11. The boy washes himself. The boy washes the shelf.*

12. This is my dog.* That is my dog.

13. The car is in the garage. Is the car in the garage?* 
NSST - Cont.

14. The boy will throw.* The boy is throwing.

15. The boy jumped. The boy jumps.*

16. Mother says, "Look who I found." Mother says, "Look what I found."*

17. Has the boy found his ball?

The boy has found his ball.*

18. This is a baby doll.* This is Baby's doll.

19. The boy is pulled by the girl.* The girl is pulled by the boy.

20. The man brings the girl the boy.* The man brings the boy the girl. 
APPENDIX D

PHOTO ARTICULATION TEST

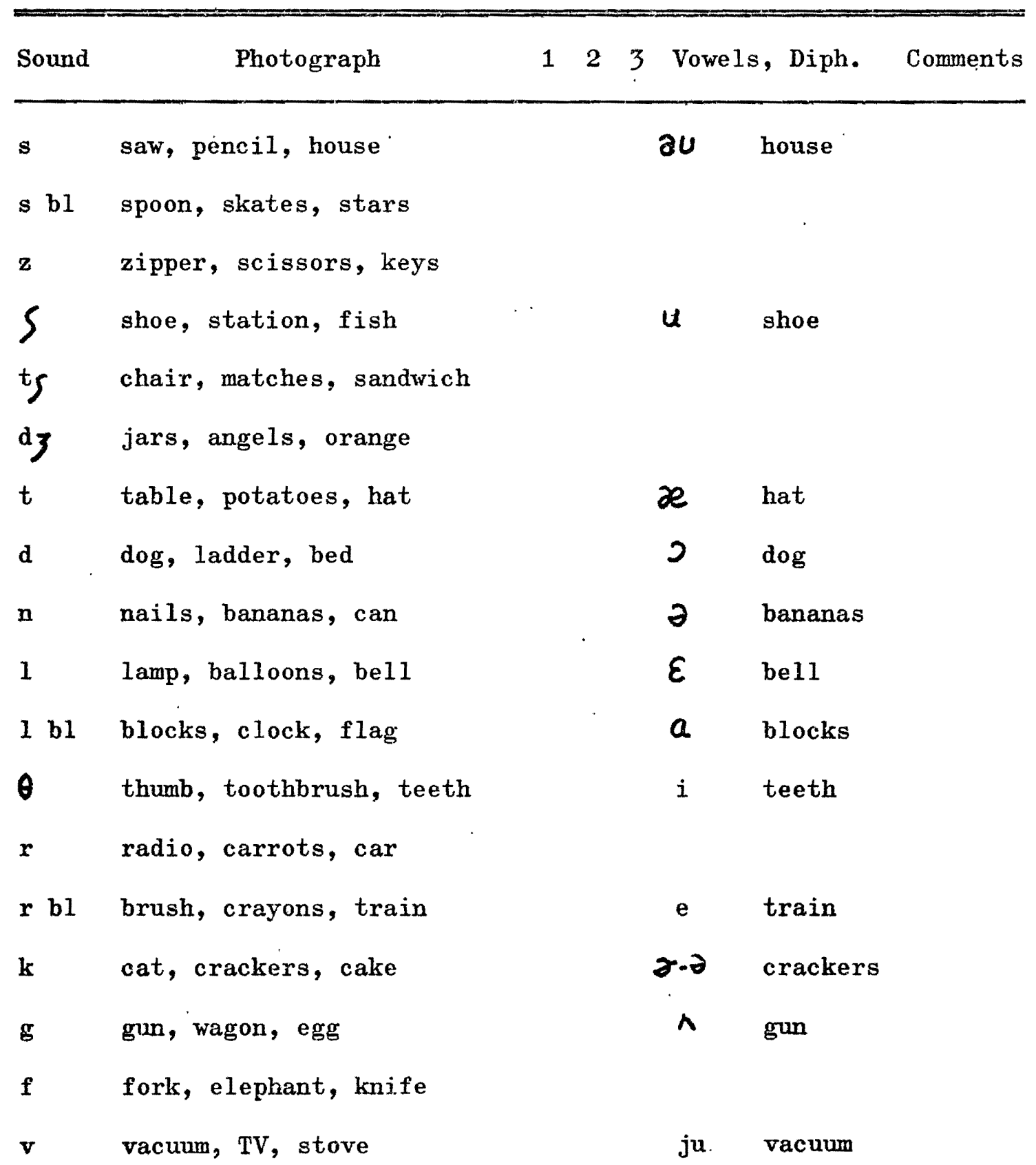


PAT - Cont.

$\Longrightarrow$

Sound Photograph $\quad 123$ Vowels, Diph. Comments

\begin{tabular}{|c|c|c|c|}
\hline $\mathbf{p}$ & pipe, apples, cup & $a \mathrm{I}$ & pipe \\
\hline $\mathbf{b}$ & book, baby, bathtub & $u$ & book \\
\hline $\mathbf{m}$ & monkey, hammer, comb & o & comb \\
\hline w-hw & witch, flowers, whistle & $I$ & witch \\
\hline$\ddot{\partial}$ & this, that, feathers, bathe & & \\
\hline$h-\eta$ & hanger, hanger, swing & & \\
\hline $\mathbf{j}$ & yes, thank you & & \\
\hline 3 & measure, beige & DI & boy \\
\hline & (story) & 3.3 & bird \\
\hline
\end{tabular}


PAT - Cont.

SUPPLEMENTARY TEST WORDS

\begin{tabular}{|c|c|c|c|c|c|c|c|}
\hline Sound & & & Consonants & & Vowe 1s & and & Diphthongs \\
\hline $\mathbf{s}$ & 1 & $\begin{array}{l}\text { same } \\
\text { set } \\
\text { sun }\end{array}$ & $\begin{array}{l}2 \text { decide } \\
\text { missing } \\
\text { myself }\end{array}$ & $\begin{array}{l}3 \text { us } \\
\text { pass } \\
\text { case }\end{array}$ & $\partial U$ & 3 & $\begin{array}{l}\text { out } \\
\text { town } \\
\text { how }\end{array}$ \\
\hline $\begin{array}{l}\text { sp } \\
\text { sk } \\
\text { st }\end{array}$ & 4 & $\begin{array}{l}\text { spoke } \\
\text { spot } \\
\text { speed }\end{array}$ & $\begin{array}{c}5 \text { skin } \\
\text { sky } \\
\text { skip }\end{array}$ & 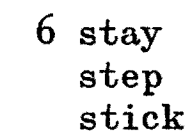 & & & \\
\hline $\mathbf{z}$ & 7 & $\begin{array}{l}\text { zoo } \\
\text { zone } \\
\text { zip }\end{array}$ & $\begin{array}{l}8 \text { easy } \\
\text { music } \\
\text { dozen }\end{array}$ & $\begin{array}{l}9 \text { has } \\
\text { is } \\
\text { use }\end{array}$ & & & \\
\hline$S$ & 10 & $\begin{array}{l}\text { she } \\
\text { shape } \\
\text { shine }\end{array}$ & $\begin{array}{l}11 \text { ocean } \\
\text { dishes } \\
\text { wishing }\end{array}$ & $\begin{array}{r}12 \text { wash } \\
\text { fish } \\
\text { push }\end{array}$ & $\mathbf{u}$ & 10 & $\begin{array}{l}\text { two } \\
\text { moon } \\
\text { who }\end{array}$ \\
\hline$t_{g}$ & 13 & $\begin{array}{l}\text { chain } \\
\text { chief } \\
\text { check }\end{array}$ & $\begin{array}{l}14 \text { catches } \\
\text { pitching } \\
\text { kitchen }\end{array}$ & $\begin{array}{l}15 \text { each } \\
\text { much } \\
\text { peach }\end{array}$ & & & \\
\hline$d_{3}$ & 16 & $\begin{array}{l}\text { John } \\
\text { joy } \\
\text { jack }\end{array}$ & $\begin{array}{l}17 \text { pages } \\
\text { magic } \\
\text { pigeon }\end{array}$ & $\begin{array}{c}18 \text { edge } \\
\text { huge } \\
\text { age }\end{array}$ & & & \\
\hline$t$ & 19 & $\begin{array}{l}\text { to } \\
\text { time } \\
\text { town }\end{array}$ & $\begin{array}{l}20 \text { valentine } \\
\text { attend } \\
\text { attack }\end{array}$ & $\begin{array}{l}21 \text { eat } \\
\text { bit } \\
\text { coat }\end{array}$ & $\partial e$ & 21 & $\begin{array}{l}\text { an } \\
\text { had } \\
\text { fat }\end{array}$ \\
\hline $\mathbf{d}$ & 22 & $\begin{array}{l}\text { day } \\
\text { done } \\
\text { do }\end{array}$ & $\begin{array}{l}23 \text { body } \\
\text { muddy } \\
\text { meadow }\end{array}$ & $\begin{aligned} & 24 \text { add } \\
& \text { head } \\
& \text { did }\end{aligned}$ & 2 & 22 & $\begin{array}{l}\text { ought } \\
\text { ball } \\
\text { paw }\end{array}$ \\
\hline $\mathbf{n}$ & 25 & $\begin{array}{l}\text { no } \\
\text { name } \\
\text { need }\end{array}$ & $\begin{array}{l}26 \text { any } \\
\text { cannot } \\
\text { minute }\end{array}$ & $\begin{array}{l}27 \text { an } \\
\text { bone } \\
\text { nine }\end{array}$ & $\partial$ & 26 & $\begin{array}{l}\text { ago } \\
\text { away } \\
\text { above }\end{array}$ \\
\hline 1 & 28 & $\begin{array}{l}\text { lay } \\
\text { lip } \\
\text { log }\end{array}$ & $\begin{array}{l}29 \text { delight } \\
\text { alone } \\
\text { fellow }\end{array}$ & $\begin{array}{ll}30 & \text { all } \\
& \text { hill } \\
& \text { deal }\end{array}$ & $\varepsilon$ & 30 & $\begin{array}{l}\text { met } \\
\text { ten } \\
\text { bed }\end{array}$ \\
\hline
\end{tabular}


PAT - Cont.

\begin{tabular}{|c|c|c|c|c|c|c|c|}
\hline Sound & & & Consonants & & Vowels & and & Diphthongs \\
\hline $\begin{array}{l}\mathrm{bl} \\
\mathrm{kl} \\
\mathrm{fl}\end{array}$ & 31 & $\begin{array}{l}\text { black } \\
\text { blow } \\
\text { blue }\end{array}$ & $\begin{array}{l}32 \text { clean } \\
\text { cloud } \\
\text { climb }\end{array}$ & $\begin{array}{l}33 \text { fly } \\
\text { flow } \\
\text { flame }\end{array}$ & $a$ & 31 & $\begin{array}{l}\text { hot } \\
\text { top } \\
\text { lock }\end{array}$ \\
\hline$\theta$ & 34 & $\begin{array}{l}\text { thick } \\
\text { thin } \\
\text { thought }\end{array}$ & $\begin{array}{l}35 \text { nothing } \\
\text { method } \\
\text { anything }\end{array}$ & $\begin{array}{l}36 \text { bath } \\
\text { death } \\
\text { mouth }\end{array}$ & i & 36 & $\begin{array}{l}\text { meat } \\
\text { we } \\
\text { weed }\end{array}$ \\
\hline $\mathbf{r}$ & 37 & $\begin{array}{l}\text { rain } \\
\text { red } \\
\text { rock }\end{array}$ & $\begin{array}{ll}38 & \text { carry } \\
\text { hurry } \\
\text { tomorrow }\end{array}$ & $\begin{array}{l}39 \text { care } \\
\text { dear } \\
\text { her }\end{array}$ & & & . \\
\hline $\begin{array}{l}\mathbf{b r} \\
\mathbf{k r} \\
\mathrm{tr}\end{array}$ & 40 & $\begin{array}{l}\text { break } \\
\text { brown } \\
\text { bread }\end{array}$ & $\begin{aligned} & 41 \text { cry } \\
& \text { crown } \\
& \text { cream }\end{aligned}$ & $\begin{array}{ll}42 & \text { tree } \\
\text { trade } \\
\text { true }\end{array}$ & e & 42 & $\begin{array}{l}\text { make } \\
\text { game } \\
\text { pain }\end{array}$ \\
\hline $\mathbf{k}$ & 43 & $\begin{array}{l}\text { came } \\
\text { keep } \\
\text { cow }\end{array}$ & $\begin{array}{l}44 \text { become } \\
\text { account } \\
\text { bucket }\end{array}$ & $\begin{array}{c}45 \text { cook } \\
\text { back } \\
\text { oak }\end{array}$ & $\partial \cdot \partial$ & 44 & $\begin{array}{l}\text { dinner } \\
\text { butter } \\
\text { winter }\end{array}$ \\
\hline $\mathbf{g}$ & 46 & $\begin{array}{l}\text { go } \\
\text { game } \\
\text { get }\end{array}$ & $\begin{aligned} & 47 \text { ago } \\
& \text { begin } \\
& \text { wagon }\end{aligned}$ & $\begin{array}{l}48 \text { bag } \\
\text { pegg } \\
\text { big }\end{array}$ & $\Lambda$ & 46 & $\begin{array}{l}\text { but } \\
\text { hum } \\
\text { fun }\end{array}$ \\
\hline $\mathbf{f}$ & 49 & $\begin{array}{l}\text { feed } \\
\text { fine } \\
\text { foot }\end{array}$ & $\begin{array}{l}50 . \text { coffee } \\
\text { often } \\
\text { beautiful }\end{array}$ & $\begin{array}{l}51 \text { half } \\
\text { enough } \\
\text { if }\end{array}$ & & & \\
\hline $\mathbf{v}$ & 52 & $\begin{array}{l}\text { view } \\
\text { vain } \\
\text { vine }\end{array}$ & $\begin{array}{l}53 \text { divide } \\
\text { even } \\
\text { heavy }\end{array}$ & $\begin{array}{l}54 \text { have } \\
\text { gave } \\
\text { five }\end{array}$ & ju & 52 & $\begin{array}{l}\text { few } \\
\text { cube } \\
\text { music }\end{array}$ \\
\hline $\mathbf{p}$ & 55 & $\begin{array}{l}\text { pay } \\
\text { put } \\
\text { pan }\end{array}$ & $\begin{array}{l}56 \text { happy } \\
\text { open } \\
\text { upon }\end{array}$ & $\begin{array}{l}57 \text { cap } \\
\text { up } \\
\text { keep }\end{array}$ & $\partial I$ & 55 & $\begin{array}{l}\text { pie } \\
\text { mine } \\
\text { hide }\end{array}$ \\
\hline $\mathbf{b}$ & 58 & $\begin{array}{l}\text { bay } \\
\text { been } \\
\text { boy }\end{array}$ & $\begin{array}{l}59 \text { about } \\
\text { nobody } \\
\text { maybe }\end{array}$ & $\begin{array}{c}60 \text { mob } \\
\text { web } \\
\text { tube }\end{array}$ & $u$ & 58 & $\begin{array}{l}\text { took } \\
\text { wood } \\
\text { put }\end{array}$ \\
\hline m & 61 & $\begin{array}{l}\text { may } \\
\text { me } \\
\text { man }\end{array}$ & $\begin{array}{c}62 \text { common } \\
\text { demand } \\
\text { mamma }\end{array}$ & $\begin{aligned} & 63 \text { am } \\
& \text { come } \\
& \text { him }\end{aligned}$ & o & 63 & $\begin{array}{l}\text { oak } \\
\text { coat } \\
\text { toe }\end{array}$ \\
\hline
\end{tabular}


PAT - Cont.

\begin{tabular}{|c|c|c|c|c|c|c|c|}
\hline Sound & & & Consenants & & Vowels & and. & Diphthongs \\
\hline$\dot{w}$ & 64 & $\begin{array}{l}\text { way } \\
\text { win } \\
\text { one }\end{array}$ & $\begin{array}{l}65 \text { away } \\
\text { anyone } \\
\text { awoke }\end{array}$ & . & $I$ & 64 & $\begin{array}{l}\text { him } \\
\text { it } \\
\text { bid }\end{array}$ \\
\hline hw & 66 & $\begin{array}{l}\text { what } \\
\text { when } \\
\text { white }\end{array}$ & $\begin{array}{l}\text { nowhere } \\
\text { awhile } \\
\text { somewhat }\end{array}$ & & & & \\
\hline ð & 67 & $\begin{array}{l}\text { they } \\
\text { them } \\
\text { the }\end{array}$ & $\begin{array}{l}67 \text { breathing } \\
\text { within } \\
\text { without }\end{array}$ & $\begin{array}{l}\text { lathe } \\
\text { smooth } \\
\text { tithe }\end{array}$ & & & \\
\hline $\mathbf{h}$ & 68 & $\begin{array}{l}\text { he } \\
\text { head } \\
\text { home }\end{array}$ & $\begin{array}{l}\text { behind } \\
\text { ahead } \\
\text { Idaho }\end{array}$ & & & & \\
\hline$\eta$ & & & $\begin{array}{l}68 \text { banging } \\
\text { donkey } \\
\text { pink }\end{array}$ & $\begin{array}{l}69 \text { hang } \\
\text { wing } \\
\text { tongue }\end{array}$ & & & \\
\hline j & & $\begin{array}{l}\text { you } \\
\text { yet } \\
\text { young }\end{array}$ & $\begin{array}{l}\text { canyon } \\
\text { lawyer } \\
\text { union }\end{array}$ & . & $2 I$ & 70 & $\begin{array}{l}\text { toy } \\
\text { annoy } \\
\text { boil }\end{array}$ \\
\hline 3 & & & $\begin{array}{l}\text { vision } \\
\text { usual } \\
\text { occasion }\end{array}$ & $\begin{array}{l}\text { rouge } \\
\text { garage } \\
\text { corsage }\end{array}$ & $3-3$ & 70 & $\begin{array}{l}\text { fux } \\
\text { dirt } \\
\text { worm }\end{array}$ \\
\hline
\end{tabular}




\section{APPENDIX E}

THE JEWISH HOSPITAL VOICE PROFILE

How long has the problem existed:

Voice Rating $\begin{array}{lllllll}1 & 2 & 3 & 4 & 5 & 6 & 7\end{array}$

In what situations is the voice better or worse? Articulation Disorder: Yes No

Length of sustained "ah"

LARYNGFAL CAVITY

PITCH

HIGH

$\mathrm{B}$
+3

$+2$

A open $-4-3-2$

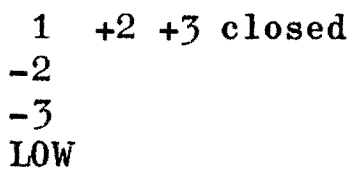

Rate
RESONATING CAVITY

NASALITY

HYPERNASAL

C

$+4$

$+3$

$+2$

$-2$

HYPONASAL

Variable

$\begin{array}{ccc}-2 & 1 & +2 \\ \text { Slow } & & \text { Fast }\end{array}$

+2
Fast

$-2$

Soft

Intensity

Vocal Range

Comments

Examiner 


\author{
APPENDIX F \\ BLOODSTEIN'S DEVELOPMENTAL PHASES OF STUTTERING
}

DLAGNOSIS AND EVALUATION

Phase 1 (Incipient)

A. Clonic Elements (Repetitions)

Repetitions of syllables and monosyllables are characteristic symptoms of this phase.

B. Tonic Elements (Hard Contacts and Prolongations)

Hard contacts not uncommon but clonic elements predominate.

C. Fluent Periods

Usually episodic. Stuttering fluctuates more widely than in any other phase.

D. Difficult Situations

Stuttering is intensified by variable sources of communicative pressure. The child is likely to have his greatest difficulty when excited or telling a long story.

E. Awareness

Does not react emotionally to himself as a stutterer.

F. Types of Words Stuttered

Stutterings tend to occur on initial word of sentence and on "small" words such as conjunctions, prepositions, and pronouns.

G. Associated or Secondary Symptoms

Not uncommon but clonic elements predominate.

H. Emotionality and Avoidance

Child generally does not react emotionally as a stutterer and speaks freely in all situations. Essentially no fear or embarrassment. 
Bloodstein's Developmental Phases etc. - Cont.

Phase 2 (Transitional)

A. Clonic Elements (Repetitions)

Repetition, hard contact, or associated mannerisms may be dominating symptoms.

B. Tonic Elements (Hard Contacts and Prolongations)

See A.

C. Fluent Periods

Essentially chronic. May disappear briefly but no longer comes in discrete episodes.

D. Difficult Situations

(Distinguishing feature of Phase 2.) Stutters primarily when he talks fast and gets excited. Stutters about equally at home, at school, or with friends.

E. Awareness

Thinks of himself as a stutterer, but continues to talk freely in all situations.

F. Types of Words Stuttered

The stutterings have attached themselves to major parts of speech.

G. Associated or Secondary Symptoms

See A.

H. Emotionality and Avoidance

Little or no concern about his stuttering except in severe cases or at rroments of unusual difficulty. 
Bloodstein's Developmental Phases etc. - Cont.

Phase 3 (Confirmed)

A. Clonic Elements (Repetitions)

(Outstanding characteristic of Phase 3.) Fully developed stuttering without avoidance of speech.

B. Tonic Elements (Hard Contacts and Prolongations)

See A.

C. Fluent Periods

Chronic.

D. Difficult Situations

Distinctiy more difficulty in some situations than in others, and is well aware of these difficult situations.

E. Awareness

Is well aware of it and acknowledges it as a personal shortcoming, even--in principle--a problem.

F. Types of Words Stuttered

In most cases word substitutions, word and sound difficulties, and, to a lesser degree, conscious anticipations are present at some time during this phase.

G. Associated or Secondary Symptoms

Elaborately developed symptomatology with postponement, starting, and release devices.

H. Emotionality and Avoidance

Dominant reaction to his stuttering when he becomes badly blocked is likely to be exasperation, annoyance or disgust. Essentially no tendency to avoid speaking nor any outward appearance of being troubled by fear or deep embarrassment. 
Bloodstein's Developmental Phases etc. - Cont.

Phase 4 (Advanced)

A. Clonic Elements (Repetitions)

See F。

B. Tonic Elements (Hard Contacts and Prolongations)

See F.

C. Fluent Periods

Chronic.

D. Difficult Situations

Vivid and continual anticipation of stuttering.

E. Awareness

Viewed by possessor as serious personal problem.

F. Types of Words Stuttered

Special difficulty in response to various sounds, words, situations, and listeners.

G. Associated or Secondary Symptoms

Fully developed symptomatology with avoidance, postponement, starting and release devices.

H. Emotionality and Avoidance

Definite emotional reactions to stuttering--avoidance of certain speaking situations, and evidences of fear and embarrassment. 


\section{APPENDIX G}

Stuttering Severify Instrument

Glyndon D. Riley

Frequency (Use $A$ or B, not both)

\begin{tabular}{cccccc}
\hline & \multicolumn{3}{c}{ A. For readers. Use land 2. } & \multicolumn{2}{c}{ B. For nonreaders } \\
\hline 1. Job Task & \multicolumn{2}{c}{ 2. Reading Task } & \multicolumn{2}{c}{ Picture Task } \\
Per- & Task & Per- & Task & Per. & Task \\
centage & Score & centage & Score & centage & Score \\
\hline 1 & 2 & 1 & 2 & 1 & 4 \\
$2-3$ & 3 & $2-3$ & 2 & $2-3$ & 6 \\
4 & 4 & $4-5$ & 5 & 4 & 8 \\
$5-6$ & 5 & $6-9$ & 6 & $5-6$ & 10 \\
$7-9$ & 6 & $10-16$ & 7 & $7-9$ & 12 \\
$10-14$ & 7 & $17-26$ & 8 & $10-14$ & 14 \\
$15-28$ & 8 & 27 and up & 9 & $15-28$ & 16 \\
29 and up & 9 & & & 29 and up & 18 \\
\hline
\end{tabular}

\section{Duration}

\begin{tabular}{lc}
\hline \hline & \\
\hline Estimated Length of Three Longest Blocks & Task Score \\
\hline Fleeting & 1 \\
One half second & 2 \\
One full second & 3 \\
2 to 9 seconds & 4 \\
10 to 30 seconds (by second hand) & 6 \\
30 to 60 seconds & 7 \\
More than 60 seconds & \\
\hline
\end{tabular}

Total

Frequency

Score

A 1 \& 2

or

B
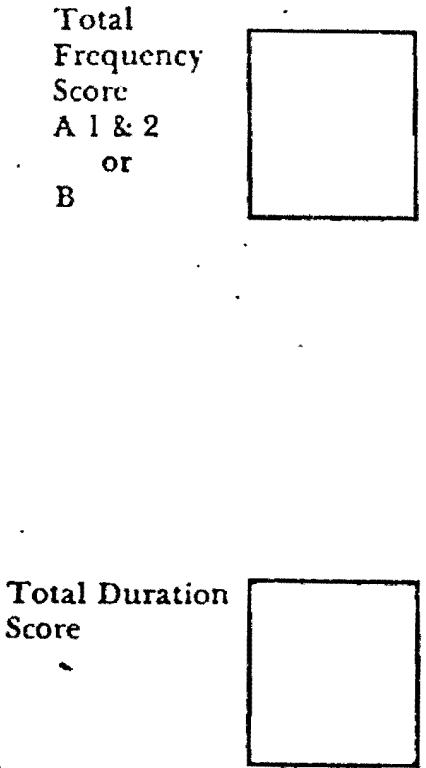

\section{Physical Concomitants}

Evaluating Scale: $0=$ uone; $1=$ not noticeable unless looking for it; 2 = barely noticeable to casual observer: 3 = distracting: $4=$ very distracting; $5=$ severe and painful looking.

1. Distracting Sounds. Noisy breathing, whistling. sniffing, blowing, clicking sounds............ 012345

2. Facial grimaces. Jaw jerking, tonguc protruding, lip pressing. jaw muscles tense............... 0122345

3. Hcad movement. Back, fonward, turning away, poor eye contact, constant looking a round....... 0.12345

4. Extremitics movement. Arm and hand movement, hands about face, torso movement. leg movements, foot tapping or swinging.

Total Physical Concomitant Score 
APPENDIX H

OSESST AND VALIDITY TESTS RAW DATA

$\underline{\text { Osesst }}$

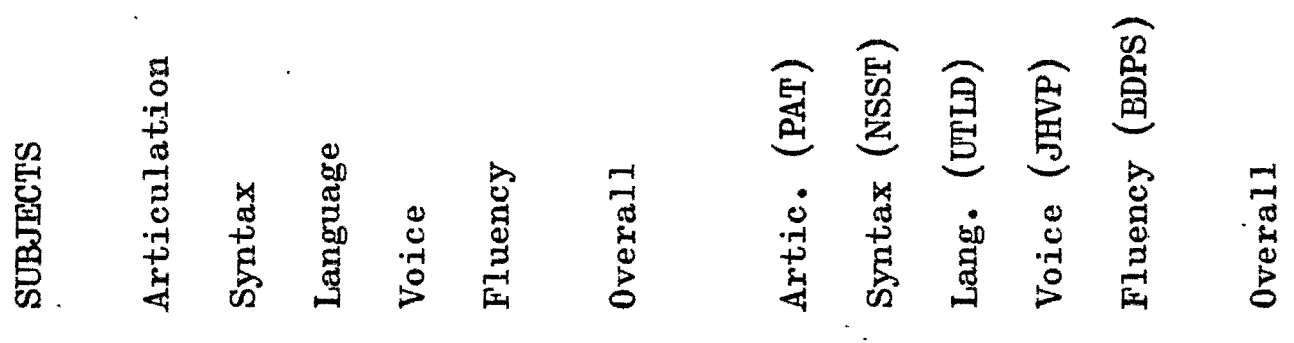

\begin{tabular}{llllllllllllll}
\hline \hline 516 & $\mathbf{P}$ & $\mathbf{P}$ & $\mathbf{P}$ & $\mathbf{P}$ & $\mathbf{P}$ & $\mathbf{P}$ & $\mathbf{P}$ & $\mathbf{P}$ & $\mathbf{P}$ & $\mathbf{P}$ & $\mathbf{P}$ & $\mathbf{P}$ \\
574 & $\mathbf{P}$ & $\mathbf{P}$ & $\mathbf{P}$ & $\mathbf{P}$ & $\mathbf{P}$ & $\mathbf{P}$ & $\mathbf{P}$ & $\mathbf{P}$ & $\mathbf{P}$ & $\mathbf{P}$ & $\mathbf{P}$ & $\mathbf{P}$ \\
596 & $\mathbf{P}$ & $\mathbf{P}$ & $\mathbf{P}$ & $\mathbf{P}$ & $\mathbf{P}$ & $\mathbf{P}$ & $\mathbf{F}$ & $\mathbf{F}$ & $\mathbf{P}$ & $\mathbf{P}$ & $\mathbf{P}$ & $\mathbf{F}$ \\
602 & $\mathbf{F}$ & $\mathbf{P}$ & $\mathbf{P}$ & $\mathbf{P}$ & $\mathbf{P}$ & $\mathbf{F}$ & $\mathbf{P}$ & $\mathbf{P}$ & $\mathbf{P}$ & $\mathbf{P}$ & $\mathbf{P}$ & $\mathbf{P}$ \\
605 & $\mathbf{P}$ & $\mathbf{P}$ & $\mathbf{P}$ & $\mathbf{P}$ & $\mathbf{P}$ & $\mathbf{P}$ & $\mathbf{F}$ & $\mathbf{P}$ & $\mathbf{P}$ & $\mathbf{P}$ & $\mathbf{P}$ & $\mathbf{F}$ \\
609 & $\mathbf{P}$ & $\mathbf{P}$ & $\mathbf{P}$ & $\mathbf{P}$ & $\mathbf{P}$ & $\mathbf{P}$ & $\mathbf{P}$ & $\mathbf{P}$ & $\mathbf{P}$ & $\mathbf{P}$ & $\mathbf{P}$ & $\mathbf{P}$ \\
613 & $\mathbf{P}$ & $\mathbf{P}$ & $\mathbf{P}$ & $\mathbf{F}$ & $\mathbf{P}$ & $\mathbf{F}$ & $\mathbf{P}$ & $\mathbf{F}$ & $\mathbf{P}$ & $\mathbf{F}$ & $\mathbf{P}$ & $\mathbf{F}$ \\
641 & $\mathbf{F}$ & $\mathbf{P}$ & $\mathbf{F}$ & $\mathbf{P}$ & $\mathbf{P}$ & $\mathbf{F}$ & $\mathbf{F}$ & $\mathbf{P}$ & $\mathbf{P}$ & $\mathbf{P}$ & $\mathbf{P}$ & $\mathbf{F}$ \\
649 & $\mathbf{P}$ & $\mathbf{P}$ & $\mathbf{F}$ & $\mathbf{P}$ & $\mathbf{P}$ & $\mathbf{F}$ & $\mathbf{P}$ & $\mathbf{F}$ & $\mathbf{F}$ & $\mathbf{P}$ & $\mathbf{P}$ & $\mathbf{F}$ \\
650 & $\mathbf{F}$ & $\mathbf{P}$ & $\mathbf{F}$ & $\mathbf{P}$ & $\mathbf{P}$ & $\mathbf{F}$ & $\mathbf{F}$ & $\mathbf{F}$ & $\mathbf{F}$ & $\mathbf{P}$ & $\mathbf{P}$ & $\mathbf{F}$ \\
652 & $\mathbf{P}$ & $\mathbf{P}$ & $\mathbf{P}$ & $\mathbf{P}$ & $\mathbf{P}$ & $\mathbf{P}$ & $\mathbf{P}$ & $\mathbf{P}$ & $\mathbf{P}$ & $\mathbf{P}$ & $\mathbf{P}$ & $\mathbf{P}$ \\
662 & $\mathbf{P}$ & $\mathbf{P}$ & $\mathbf{P}$ & $\mathbf{P}$ & $\mathbf{P}$ & $\mathbf{P}$ & $\mathbf{F}$ & $\mathbf{P}$ & $\mathbf{P}$ & $\mathbf{P}$ & $\mathbf{P}$ & $\mathbf{F}$ \\
673 & $\mathbf{P}$ & $\mathbf{P}$ & $\mathbf{F}$ & $\mathbf{P}$ & $\mathbf{P}$ & $\mathbf{F}$ & $\mathbf{P}$ & $\mathbf{P}$ & $\mathbf{P}$ & $\mathbf{P}$ & $\mathbf{P}$ & $\mathbf{P}$ \\
680 & $\mathbf{P}$ & $\mathbf{P}$ & $\mathbf{P}$ & $\mathbf{P}$ & $\mathbf{P}$ & $\mathbf{P}$ & $\mathbf{P}$ & $\mathbf{P}$ & $\mathbf{P}$ & $\mathbf{P}$ & $\mathbf{P}$ & $\mathbf{P}$ \\
681 & $\mathbf{P}$ & $\mathbf{P}$ & $\mathbf{F}$ & $\mathbf{P}$ & $\mathbf{P}$ & $\mathbf{F}$ & $\mathbf{P}$ & $\mathbf{P}$ & $\mathbf{P}$ & $\mathbf{P}$ & $\mathbf{P}$ & $\mathbf{P}$ \\
687 & $\mathbf{P}$ & $\mathbf{P}$ & $\mathbf{P}$ & $\mathbf{P}$ & $\mathbf{P}$ & $\mathbf{P}$ & $\mathbf{P}$ & $\mathbf{P}$ & $\mathbf{P}$ & $\mathbf{P}$ & $\mathbf{P}$ & $\mathbf{P}$ \\
693 & $\mathbf{P}$ & $\mathbf{P}$ & $\mathbf{P}$ & $\mathbf{P}$ & $\mathbf{P}$ & $\mathbf{P}$ & $\mathbf{F}$ & $\mathbf{P}$ & $\mathbf{P}$ & $\mathbf{P}$ & $\mathbf{P}$ & $\mathbf{F}$ \\
703 & $\mathbf{P}$ & $\mathbf{P}$ & $\mathbf{P}$ & $\mathbf{P}$ & $\mathbf{P}$ & $\mathbf{P}$ & $\mathbf{P}$ & $\mathbf{P}$ & $\mathbf{P}$ & $\mathbf{P}$ & $\mathbf{P}$ & $\mathbf{P}$ \\
705 & $\mathbf{F}$ & $\mathbf{P}$ & $\mathbf{P}$ & $\mathbf{P}$ & $\mathbf{P}$ & $\mathbf{F}$ & $\mathbf{F}$ & $\mathbf{P}$ & $\mathbf{F}$ & $\mathbf{P}$ & $\mathbf{P}$ & $\mathbf{F}$
\end{tabular}


Raw Data - Cont.

$\underline{\text { 0sesst }}$

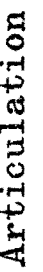

Validity

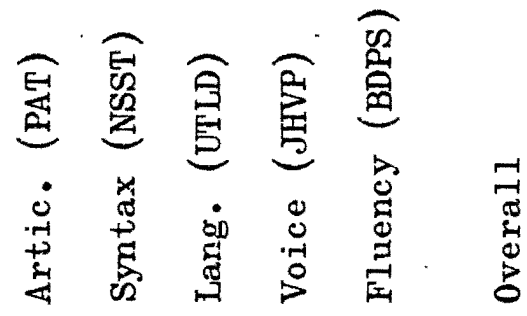

$\begin{array}{lllllll}712 & \mathbf{P} & \mathbf{P} & \mathbf{P} & \mathbf{P} & \mathbf{P} & \mathbf{P}\end{array}$ $\begin{array}{lllllll}717 & \mathbf{P} & \mathbf{P} & \mathbf{P} & \mathbf{P} & \mathbf{P} & \mathbf{P}\end{array}$ $\begin{array}{lllllll}720 & \mathbf{P} & \mathbf{P} & \mathbf{F} & \mathbf{P} & \mathbf{P} & \mathbf{F}\end{array}$ $\begin{array}{lllllll}722 & \mathbf{P} & \mathbf{P} & \mathbf{P} & \mathbf{P} & \mathbf{P} & \mathbf{P}\end{array}$ $\begin{array}{lllllll}739 & \mathbf{F} & \mathbf{P} & \mathbf{P} & \mathbf{P} & \mathbf{P} & \mathbf{F}\end{array}$ $\begin{array}{lllllll}741 & P & P & P & P & P & P\end{array}$ $\begin{array}{lllllll}745 & \mathbf{P} & \mathbf{P} & \mathbf{P} & \mathbf{P} & \mathbf{P} & \mathbf{P}\end{array}$ $\begin{array}{lllllll}746 & \mathbf{P} & \mathbf{P} & \mathbf{P} & \mathbf{F} & \mathbf{P} & \mathrm{F}\end{array}$ $\begin{array}{lllllll}749 & \mathbf{F} & \mathbf{P} & \mathbf{P} & \mathbf{P} & \mathbf{P} & \mathbf{F}\end{array}$ $\begin{array}{lllllll}903 & \mathbf{P} & \mathbf{P} & \mathbf{P} & \mathbf{P} & \mathbf{P} & \mathbf{P}\end{array}$ $\begin{array}{lllllll}920 & \mathbf{P} & \mathbf{P} & \mathbf{P} & \mathbf{P} & \mathbf{P} & \mathbf{P}\end{array}$ $\begin{array}{lllllll}925 & \mathbf{P} & \mathbf{P} & \mathbf{F} & \mathbf{P} & \mathbf{P} & \mathbf{F}\end{array}$ $\begin{array}{lllllll}930 & \mathbf{F} & \mathbf{P} & \mathbf{P} & \mathbf{P} & \mathbf{P} & \mathbf{F}\end{array}$ $\begin{array}{lllllll}931 & \mathbf{P} & \mathbf{P} & \mathbf{P} & \mathbf{P} & \mathbf{P} & \mathbf{P}\end{array}$ $\begin{array}{lllllll}932 & \mathbf{P} & \mathbf{P} & \mathbf{F} & \mathbf{P} & \mathbf{P} & \mathbf{F}\end{array}$ $\begin{array}{lllllll}933 & \mathbf{P} & \mathbf{P} & \mathbf{F} & \mathbf{P} & \mathbf{P} & \mathbf{F}\end{array}$ $\begin{array}{lllllll}936 & F & P & P & P & P & F\end{array}$ $\begin{array}{lllllll}943 & P & P & F & P & P & F\end{array}$ $\begin{array}{lllllll}964 & \mathbf{P} & \mathbf{P} & \mathbf{P} & \mathbf{P} & \mathbf{P} & \mathbf{P}\end{array}$ $\begin{array}{lllllll}966 & \mathbf{P} & \mathbf{P} & \mathbf{P} & \mathbf{P} & \mathbf{P} & \mathbf{P}\end{array}$ $\begin{array}{lllllll}968 & F & P & F & F & P & F\end{array}$

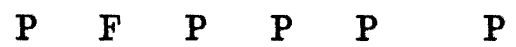

$\begin{array}{llllll}\mathbf{P} & \mathbf{P} & \mathbf{P} & \mathbf{P} & \mathbf{P} & \mathbf{P}\end{array}$ $\begin{array}{llllll}\mathbf{P} & \mathbf{P} & \mathbf{P} & \mathbf{P} & \mathbf{P} & \mathbf{P}\end{array}$ $\begin{array}{llllll}\mathbf{P} & \mathbf{P} & \mathbf{P} & \mathbf{P} & \mathbf{P} & \mathbf{P}\end{array}$ $\begin{array}{llllll}\mathbf{F} & \mathbf{P} & \mathbf{P} & \mathbf{P} & \mathbf{P} & \mathbf{F}\end{array}$ $\begin{array}{llllll}\mathbf{P} & \mathbf{P} & \mathbf{P} & \mathbf{P} & \mathbf{P} & \mathbf{P}\end{array}$ $\begin{array}{llllll}\mathbf{P} & \mathbf{F} & \mathbf{P} & \mathbf{P} & \mathbf{P} & \mathbf{P}\end{array}$ $\begin{array}{llllll}\mathbf{P} & \mathbf{P} & \mathbf{P} & \mathbf{F} & \mathbf{P} & \mathbf{F}\end{array}$ $\begin{array}{llllll}\mathbf{F} & \mathbf{P} & \mathbf{P} & \mathbf{P} & \mathbf{P} & \mathbf{F}\end{array}$ $\begin{array}{llllll}F & F & F & P & P & F\end{array}$ $\begin{array}{llllll}\mathbf{F} & \mathbf{P} & \mathbf{P} & \mathbf{P} & \mathbf{P} & \mathbf{F}\end{array}$ $\begin{array}{llllll}\mathbf{F} & \mathbf{P} & \mathbf{F} & \mathbf{P} & \mathbf{P} & \mathbf{F}\end{array}$ $\begin{array}{llllll}F & F & P & P & P & F\end{array}$ $\begin{array}{llllll}\mathbf{P} & \mathbf{P} & \mathbf{P} & \mathbf{P} & \mathbf{P} & \mathbf{P}\end{array}$ $\begin{array}{llllll}\mathbf{P} & \mathbf{P} & \mathbf{F} & \mathbf{P} & \mathbf{P} & \mathbf{F}\end{array}$ $\begin{array}{llllll}\mathbf{P} & \mathbf{F} & \mathbf{F} & \mathbf{P} & \mathbf{P} & \mathbf{F}\end{array}$ $\begin{array}{llllll}\mathbf{F} & \mathbf{P} & \mathbf{P} & \mathbf{P} & \mathbf{P} & \mathbf{F}\end{array}$ $\begin{array}{llllll}\mathbf{P} & \mathbf{P} & \mathbf{F} & \mathbf{P} & \mathbf{P} & \mathbf{F}\end{array}$ $\begin{array}{llllll}\mathbf{P} & \mathbf{P} & \mathbf{P} & \mathbf{P} & \mathbf{P} & \mathbf{P}\end{array}$ $\begin{array}{llllll}\mathbf{P} & \mathbf{P} & \mathbf{P} & \mathbf{P} & \mathbf{P} & \mathbf{P}\end{array}$ $\begin{array}{llllll}\mathbf{F} & \mathbf{P} & \mathbf{F} & \mathbf{F} & \mathbf{P} & \mathbf{F}\end{array}$ 